Is the critical, academic study of the Bible inextricably bound to the destinies of theology?

Uehlinger, Christoph

Posted at the Zurich Open Repository and Archive, University of Zurich

ZORA URL: https://doi.org/10.5167/uzh-118028

Book Section

Published Version

Originally published at:

Uehlinger, Christoph (2015). Is the critical, academic study of the Bible inextricably bound to the destinies of theology? In: Grabbe, Lester L; Korpel, Marjo. Open-mindedness in the Bible and Beyond. A Volume of Studies in Honour of Bob Becking. London: Bloomsbury Academic, 287-302. 


\section{OPEN-MINDEDNESS IN THE BIBLE AND BEYOND}

\section{A Volume of Studies in Honour of Bob Becking}

Edited by Marjo C. A. Korpel and Lester L. Grabbe

Bloomsbury T\&T Clark

An imprint of Bloomsbury Publishing Plc

$\begin{array}{llllllllll}\text { B } & \mathrm{L} & \mathrm{O} & \mathrm{O} & \mathrm{M} & \mathrm{S} & \mathrm{B} & \mathrm{U} & \mathrm{R} & \mathrm{Y}\end{array}$

LONDON • NEW DELHI $・$ NEW YORK $・$ SYDNEY 


\section{LIBRARY OF HEBREW BIBLE/ \\ OLD TESTAMENT STUDIES}

\section{6}

Formerly Journal for the Study of the Old Testament Supplement Series

Editors

Claudia V. Camp, Texas Christian University

Andrew Mein, Westcott House, Cambridge

Founding Editors

David J. A. Clines, Philip R. Davies and David M. Gunn

\section{Editorial Board}

Alan Cooper, John Goldingay, Robert P. Gordon,

Norman K. Gottwald, James E. Harding, John Jarick, Carol Meyers,

Carolyn J. Sharp, Daniel L. Smith-Christopher,

Francesca Stavrakopoulou, James W. Watts

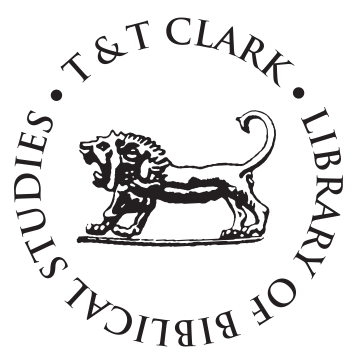




\section{Bloomsbury T\&T Clark}

An imprint of Bloomsbury Publishing Plc

Imprint previously known as T\&T Clark

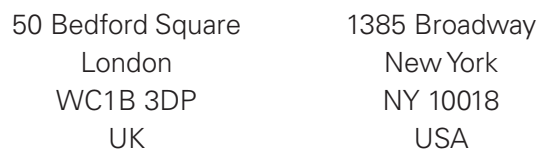

www.bloomsbury.com

\section{BLOOMSBURY, T\&T CLARK and the Diana logo are trademarks of Bloomsbury Publishing Plc}

First published 2015

(C) Marjo C. A. Korpel and Lester L. Grabbe, 2015

Marjo C. A. Korpel and Lester L. Grabbe have asserted their rights under the Copyright, Designs and Patents Act, 1988, to be identified as Editors of this work.

All rights reserved. No part of this publication may be reproduced or transmitted in any form or by any means, electronic or mechanical, including photocopying, recording, or any information storage or retrieval system, without prior permission in writing from the publishers.

No responsibility for loss caused to any individual or organization acting on or refraining from action as a result of the material in this publication can be accepted by Bloomsbury or the authors.

\section{British Library Cataloguing-in-Publication Data}

A catalogue record for this book is available from the British Library.

ISBN: HB: 978-0-56766-380-1 ePDF: 978-0-56766-379-5

Library of Congress Cataloging-in-Publication Data

A catalog record for this book is available from the Library of Congress.

Series: Library of Hebrew Bible/Old Testament Studies, volume 616

Typeset by Fakenham Prepress Solutions, Fakenham, Norfolk NR21 8NN Printed and bound in Great Britain 


\section{CONTENTS}

Contributors viii

Acknowledgements $\quad x$

Introduction (Lester L. Grabbe and Marjo C. A. Korpel)

Professor Bob Becking $\quad$ xi

Summaries of Papers xiv

Bibliography of Professor Bob Becking xxi

List of Abbreviations $\quad$ xxxvii

OPEN-MINDEDNESS FOR UNDERSTANDING THE FORMATION OF THE

PENTATEUCH: THE CHALLENGE OF EXODUS 19-20

Rainer Albertz

EMPIRE! ‘... AND GAVE HIM A SEAT ABOVE THE SEATS OF THE OTHER KINGS WHO WERE WITH HIM IN BABYLON’: JEREMIAH 52.31-34:

FACT OR FICTION?

Hans M. Barstad

BEN SIRA AND SONG OF SONGS: WHAT ABOUT PARALLELS AND

ECHOES?

Pancratius C. Beentjes

OPEN-MINDEDNESS AND PLANNING FOR THE FUTURE OF ACADEMIC STUDIES IN ANCIENT ISRAEL HISTORY

Ehud Ben Zvi

ISAIAH 24-27: SPACING A PROPHETIC VISION

Willem A. M. Beuken

EINÜBUNG IN DEN AUFRECHTEN GANG: BEISPIELE FÜR ZIVILCOURAGE IN DEN SAMUELBÜCHERN

Walter Dietrich

SWORDS OR PLOUGHSHARES? THE TRANSITION FROM THE LATE BRONZE TO THE EARLY IRON AGE IN NORTHERN JORDAN

Meindert Dijkstra and Karel Vriezen 
PENETRATING THE LEGEND: IN QUEST OF THE HISTORICAL EZRA Lester L. Grabbe

JOSEPH, THE PASTOR AND THE CONQUEROR OF EVIL BY USING GOOD: OBSERVATIONS ON GENESIS 50.15-21 IN DUTCH CHILDREN'S AND FAMILY BIBLES

Cornelis Houtman

THE MYTH OF THE REBORN NATION

Izaak J. de Hulster

LEADING SCHOLARS AND THE INTERPRETATION OF SCRIPTURE: THE CASE OF LXX HAGGAI 2.1-9

Arie van der Kooij

MEMORIES OF EXILE AND RETURN IN THE BOOK OF RUTH Marjo C. A. Korpel

THE QUESTION OF JOB

Peter Machinist 165

THE OPEN MIND OF THE MAN BORN BLIND (JOHN 9)

Maarten J. J. Menken

JERUSALEM: NIGHTMARE AND DAYDREAM IN MICAH Johannes C. de Moor

FOUR NOTES ON THE ANCIENT NEAR EASTERN MARZEAH Nadav Na'aman

THE ABOLITION OF THE CULT OF THE DEAD KINGS IN JERUSALEM (EZEKIEL 43.6-9)

Herbert Niehr

A HUMAN AND A DEITY WITH CONFLICTING MORALS

(QOHELET 2.26)

Paul Sanders

A PROPHET CONTEST: JEREMIAH 28 RECONSIDERED

Klaas A. D. Smelik

COMPARING THE BOOK OF JUDGES TO GREEK LITERATURE

Klaas Spronk 
SPEAKING OF GODS: DIMENSIONS OF THE DIVINE IN THE ANCIENT NEAR EAST

Karel van der Toorn

IS THE CRITICAL, ACADEMIC STUDY OF THE BIBLE INEXTRICABLY BOUND TO THE DESTINIES OF THEOLOGY?

Christoph Uehlinger

BIBLICAL STUDIES AND THE ART OF CIVILIZATION MAINTENANCE

Anne-Mareike Wetter

A NEW DIVINE TITLE IN ISAIAH 10.17

H. G. M. Williamson

Bibliography

321

Index of Biblical Texts

359

Index of Names and Subjects

373

Index of Names

377 


\title{
IS THE CRITICAL, ACADEMIC STUDY OF THE BIBLE INEXTRICABLY BOUND TO THE DESTINIES OF THEOLOGY?
}

\author{
Christoph Uehlinger \\ University of Zürich, Switzerland
}

In den seltensten Fällen passen institutionelle Organisation einerseits und Struktur des wissenschaftlichen Arbeitens zusammen - allein schon deshalb, weil die Organisation meist eine Problembearbeitung zum Ausdruck bringt, die bereits überholt ist, aber auch deshalb, weil viele sachfremde Bedingungen des Umfelds die Gestaltungsmöglichkeiten bestimmen. Deshalb ist es gut, wenn man gelegentlich über die Bücher geht und überlegt, ob man die Organisationsform nicht einer neuen Problemlage anpassen sollte. ${ }^{1}$

\section{Introduction}

Readers of this volume in honour of Bob Becking might have raised eyebrows at the title of this contribution. Why, one may ask, should the critical, academic study of the Bible be inextricably linked to theology - since the Bible as an object of study, while enjoying a special status in Christian (and, somewhat differently, in Jewish) theology, can well be addressed as literature, as a product of history, a monument of language and language history (from Hebrew and Greek to modern translations), a cultural artefact (indeed an ancient library of sorts, transmitted over many centuries), a medium serving various purposes in religion (from ritual to doctrinal), an intellectual resource and inspiration for the arts (literature,

1. Stolz 1998: 173 (= 2004: 304). ET: 'A match between an institution on the one hand and the structure of academic work on the other is a rarity - not only because the institution usually represents a kind of problem-solving mechanism that is already obsolete, but also because many extraneous conditions determine the opportunities for creativity. Therefore, it is good to occasionally reconsider the situation and ask whether the structure of the organization ought not to be adapted to a changed set of challenges.' 
visual arts, music ...) and popular culture (film, comics ...), an explicit or implicit referent for educated social discourse (in philosophy, ethics, politics, economics ... ), etc., etc.? The Bible, one should think when considering this non-exhaustive list, must concern academic fields and disciplines as diverse as languages and literature, history from ancient to modern, religious studies (whether comparative or tradition-focused), art history, cultural and media studies, musicology, the history and sociology of knowledge, etc.

To be sure, the study of the Bible is also an important, if not always an essential part of Hebrew Studies, Jewish Studies, 'Ancient Studies', disciplines taught in many universities around the world. From the perspective of these disciplines, the title question may easily be answered by the negative. It seems to make no sense at all in academic contexts where 'Biblical Studies' (the critical, academic study of the Bible par excellence) represent a full-fledged discipline of its own. Wherever the Bible is studied in the framework of one of these disciplines, within or alongside departments of Jewish Studies, Ancient History or Religious Studies/ Comparative Religion, ${ }^{2}$ this is usually done in a Faculty of Humanities and/or Letters and most often (though not exclusively) in a secular environment. Such is the case, for instance, in many universities in Israel, the USA, Australia, South Africa and other countries (including in Britain, especially in recent years). Whatever future these disciplines may have in their various contexts, it does not seem to be directly related to the destinies of theology.

\section{The Place of Biblical Studies in Europe}

The situation is different, however, in most countries of Western, Central and Eastern Europe, where the critical, academic study of the Bible is, as a rule, closely if not exclusively linked to faculties and institutes of Christian (Catholic, Orthodox, Protestant...) theology. Wherever theology has a place in public, state-run universities, the critical study of the Bible is a major, indeed foundational, theological discipline. It stands to reason that this peculiar arrangement is a European characteristic.

The reasons for this institutional arrangement are first of all historical: academic biblical studies first developed in Europe (Sæbø 2008); they did so out of Humanist Philologia Sacra, the philological study of Holy Scripture (Sacra Scriptura), that is the Old and New Testament to which Christian religion and theology attribute special, though not exclusive, quality in revelation. (More softly stated, this could also be termed the Bible's hermeneutical quality and significance for theology, the Church and the faithful.) Biblical philology (soon to be joined by antiquarianism, then supplemented by history, archaeology, epigraphy, etc.) was and still is thought by many to be the critical, scholarly starting-point for biblical (theological) exegesis, that is, an adequate understanding of the Bible's message for the contemporary reader (however one wishes to define the criteria of

2. See below, note 7 , on terminology. 
adequacy, which may range from philological and historical criticism to homiletic appropriation).

To be sure, throughout European intellectual history the Bible has rarely been studied and interpreted in isolation, at least among critical scholars. Scholars have placed it alongside non-Christian, even non-religious, works of literature or philosophy since Renaissance humanism. ${ }^{3}$ Moreover, as mentioned above, the Bible has long been an object of interest and intellectual curiosity far beyond religious circles, and one can hardly exaggerate the importance it has held in erudite discussions in European sciences, arts, letters, etc. from the fourteenth century to the modern period. This notwithstanding, the critical, academic study of the Bible as organized and institutionalized in (Western, Central, Eastern) European universities has, to the best of my knowledge, never developed into a fully autonomous, self-contained academic discipline ('Biblical Studies'), nor has it been consistently approached as an independent sub-field of other disciplines than theology. ${ }^{4}$ As mentioned, this seems to be a European characteristic.

One could imagine alternative institutional arrangements, in which the study of the Bible would be based on an exclusively secular, philological, historical and culture-critical endeavour, unrelated or with no privileged connection to theology. To the best of my knowledge, however, such alternatives have rarely materialized in European universities, unless under exceptional circumstances. As a rule, the critical, academic study of the Bible flourished in Europe in close epistemic solidarity with Christian theology; in contrast, wherever some form of

3. But see below on the exclusion of the Bible from Friedrich Max Müller's Sacred Texts of the East, which resulted from restrictions by theologians who were eager to safeguard what they considered to be the Bible's exceptional status as Holy Scripture and normative revelation, not to be mixed up with the canonical writings of other religious traditions.

4. This statement requires qualification in view of the European Association of Biblical Studies, which does not particularly favour theological approaches to biblical literature. The EABS presentation on http://www.eabs.net/site/about-overview/about-us/ welcomes a diversity of approaches and explicitly refers to areas as diverse as Archaeology, History, Hebrew Bible, Early Judaism, Talmud, New Testament, Early Christianity and Patristics. In contrast, no mention is made of theology and theologically informed approaches to the Bible. This is surprising in view of the fact that Theological Faculties probably provide the institutional background to a large part, if not the majority of EABS members. When observed from a distance, it seems that possible epistemological constraints due to actual institutional arrangements, whether secular or theological, are neither fully spelled out nor perhaps consciously reflected in EABS documents.

One may add that study programmes entitled 'Biblical Studies' and the like are offered as minors or majors in many European universities. However, the relevant curricula rarely represent an independent track or follow a strictly non-theological curriculum, but more often than not they consist of a more or less random selection of courses offered within the broader curriculum of biblical studies and their Hilfswissenschaften in Faculties of Theology. In reality, therefore, these programmes rarely represent a truly secular alternative to theology-related biblical studies. 
(Christian) theology did not find its place in or was banned from public universities, biblical studies too remained virtually non-existent.

Stepping back and considering this situation from a distance, one may ask

(a) whether the privileged conjunction of the academic study of the Bible with theology (what I consider to be a characteristically European arrangement) is necessary and appropriate beyond the contingencies of historical explanation;

(b) whether it can be considered to be beneficial to either partner - and to other disciplines - under all circumstances; or

(c) whether the conjunction of biblical studies and theology might also have had some detrimental side-effects, not least on disciplines excluded by the arrangement. One may further ask

(d) whether such side-effects could be avoided or minimized by way of alternative institutional arrangements.

Is it possible, perhaps even desirable, to imagine such arrangements that would question, relativize and maybe even cancel the privileged link between the critical, academic study of the Bible and theology? Is it conceivable that such arrangements might better account especially for non-theological disciplines and interests? Our tentative, non-exhaustive listing has shown that they are numerous and cannot easily be dismissed as a quantité négligeable. Might such alternative arrangements perhaps be more appropriate to presently changing circumstances in academia in Europe, too, and should they therefore be encouraged?

The purpose of this paper is not to provide straightforward answers to the above-mentioned questions but to raise these questions in the first place. ${ }^{5} \mathrm{My}$ remarks would be misunderstood if read as a pamphletary call for radical change. I have no other agenda than to raise questions which, I think, are timely in view of ongoing transformations in European academia. The following reflections only want to address, by way of questions and imagination, a few possibilities and options that seem not yet to have been fully explored nor put into practice or tested, to the best of my knowledge, in our academic conversations and arrangements.

\section{A Personal Remark}

Encouraged by the editors' invitation to celebrate Bob Becking's open-mindedness, my reflections are nourished by personal experience as much as by sympathy.

Personal experience because, as a former biblical scholar having spent roughly 20 years in a distinguished theological environment (the University of Fribourg's

5. Maybe the EABS (above, note 4) should organize a consultation on such questions among its members, or stage a conference where they could be debated? 
very Catholic Faculty of Theology), ${ }^{6}$ I find myself now teaching and researching for more than a decade in a sensibly different institutional environment. The Institute of 'Religious Studies' of the University of Zürich (UZH), though part of the Faculty of Theology for weighty historical ${ }^{8}$ and other good reasons, considers itself and is today considered by faculty and university authorities alike a distinctly non-theological entity, an enclave of sorts within the Faculty of Theology and at the same time a bridge to the Faculty of Letters, with which we entertain as much stimulating and fruitful cooperation as with our colleagues of the theological tribe. ${ }^{9}$ Having changed sides in more than one respect: from a relatively small ('provincial' however 'catholic') university to a big university in a cosmopolitan city; from a Roman-Catholic to a Protestant faculty; from a discourse community where theologians form the majority, to another where I find myself in the company of historians and (post-)'Orientalists'; from biblical studies operating within a theological framework to the methodologically agnostic study of religion(s) (History of Religions/Comparative Religion) - all this has made me experience and reflect time and again on the contingency, reality and effects of particular institutional arrangements, disciplinary boundaries and academic discourse communities.

'Sympathy' because, I am told, biblical studies and scholars working in this field in the Netherlands have been considerably affected by recent institutional realignments and drastic budgetary cuts, decided by governors for reasons that are unknown to me, but which cannot be based on a scholarly evaluation. ${ }^{10} \mathrm{Be}$

6. See Uehlinger 2003. Although subjectively, from my own point of view, I had always understood my previous work as a Hebrew Bible scholar interested in ancient Near Eastern iconography and religion as fully compatible with a theological framework, I apparently did not succeed in making my point fully understandable (or acceptable) to some of my former colleagues.

7. Note that this notoriously ambiguous designation has been imposed on our Religionswissenschaftliches Seminar by an office of the central administration in charge of UZH's nomenclature. This is not the place to quibble over terminology, but my own preference goes for 'Study of Religion(s)' to designate the field or discipline, and I find my own work best reflected in 'History of Religions/Comparative Religion', which I consider as a sub-discipline of the former.

8. Stolz 1998; Uehlinger 2010.

9. Terminology here, as with 'clans' a littler earlier, is loosely indebted to Becher and Trowler 1989 (2001).

10. I shall not comment on specific developments in the Netherlands, since I lack sufficiently detailed information on their background, but I am aware that the formerly-held mixed regime, which accepted biblical studies and other philological-historical disciplines in universities run by the state but required the Churches to take charge of systematic and pastoral theology, has been disrupted. As a result, several faculties of theology with a long-standing history and excellent academic record (among them Utrecht University, an eminent member of the League of European Research Universities, as well as Leiden University) have been dissolved, hitting de plein fouet distinguished and internationally 
it only for circumstantial reasons, then, it seems legitimate and timely to ask the question formulated in my title.

\section{Is the Conjunction of Biblical Studies and Theology a Necessary One?}

The first of our four questions can be quite easily answered, but the answer will depend on the point of view from which we consider the relationship. From the perspective of theology, it seems hard to conceive of this discipline without a constituent part of biblical studies. A relationship considered to be necessary is almost naturally bound to be a complicated one, since one partner's expectations risk being (or can be felt to be) imposed on the other rather than naturally looked for by him; the effects will then be inhibiting rather than stimulating, or alienating instead of strengthening one's partner.

Theological expectations may vary from doctrinal alignment through moral education to pastoral utility, none of which are regarded by critical biblical scholars as essential values that should govern their textual analysis and interpretation. On the other hand, biblical scholars who think that their critical study of the Bible should impact systematic and/or pastoral theology at all are more easily inclined to expect that theological teachings should adapt to new findings in biblical scholarship rather than the other way round. Thus the two clans of the theological community (biblical scholars and historians vs. systematic and practical theologians) each place expectations on the other to which the latter generally refuses to conform. Readers familiar with Theological Faculties know about habitual tensions between the two clans. Needless to say, sophisticated theological discourse rarely expresses this tension as straightforwardly or bluntly as I did here. But practitioners of academic theology will have recognized in this caricature situations well-known from their own experience. As a matter of fact, such tensions do occur among faculty members, or between faculty members and students, and cannot always be resolved.

Viewed from the opposite perspective, of biblical studies in a broader sense, the critical study of the Bible extends far beyond theology, at times to the extent that theological concerns are simply ignored. Prioritized research questions in biblical studies are concerned with language, literature, history, archaeology, culture, etc. From this perspective (which the other clan will perhaps suspect to be reductive or reductionist), the question whether biblical studies entertains an essential and necessary relationship to theology is easily answered: No.

To sum up, if theology may be a legitimate framework within which one can indeed practise critical, academic biblical scholarship, it is by no means the only framework nor a necessary one for biblical studies.

respected scholars. These transformations will not only affect theology, and biblical studies for certain, but will have considerable implications and consequences for the study of religion(s) as a whole. 


\section{Is the Conjunction of Biblical Studies and Theology always a Beneficial One?}

Answers to this second question will again depend on one's perspective and interest. We should start by clarifying the terms: Should we consider whether the two mentioned partners (theology and biblical studies) find common or mutual benefit in their privileged interaction (or not); whether one of the two is taking advantage (or not) from interaction with the other; or whether other players might benefit (or not) from a situation of privileged interaction between the two partners mentioned?

In the first case, evaluations will vary along the same options as I have just discussed. One should also point out, however, an essential feature of theology: a self-reflective system in which two unequal partners must cooperate promises to be intellectually dynamic precisely because of potentially conflicting interests. On the one hand, systematic and practical theologians aim at exposing the meaning of Christian faith to present-day believers; on the other, biblical scholars (and fellow Church historians) work with historical-critical methods, employing themselves to re-connect biblical and other ancient texts to their antique social, cultural, literary and ideological contexts, an enterprise which produces considerable a-chronicity and estrangement. Such a situation of tension between ancient texts and modern readers represents a hermeneutic challenge and promises intellectual benefit.

Scholars who support a harmonious understanding of theology will also argue that progress in knowledge in one or another field of theology will naturally lead to the overall system's increasing complexity and sophistication, a process which academics are inclined to value as such, regardless of any particular outcome. The everyday faculty reality is of course more prosaic: as a rule, actors in one field (theology or biblical studies) are eager to impart complexity and sophistication to their own area of expertise, but they remain relatively indifferent to complexity and sophistication in a field which is not their own. Here as in any other academic discipline, selective interest and indifference are the price to pay for specialization. When observing the arena from its margins, one recognizes that there is a considerable hiatus between theological assumptions and postulates on the one hand (e.g. that the Bible is norma normans for Catholics, or to Protestants provides the exclusive key [Sola Scriptura] to faith) and the polite mutual ignorance with which members of one clan (biblical scholars and historians) consider the other (systematic and practical theologians), and vice versa. For either side it is often hard to recognize real progress in the other clan's scholarship and sub-disciplinary discourse.

This being sceptically stated, there are of course situations where findings in one field may trigger new questions, or new approaches in the other field. The necessary condition for such a thing to occur is that people on one side of the divide be aware of what happens on the other. Again, when observing the arena from a certain distance, it seems to me that biblical scholars are generally more curious about and tuned to advances in the neighbouring fields of ancient history, archaeology, ancient Near Eastern studies, Egyptology or Graeco-Roman and Hellenistic studies, linguistics, literary or cultural studies rather than to new options in systematic and pastoral theology; while colleagues of the latter fields 
will devote more attention to philosophy, literature and the arts or psychology and social sciences than to biblical studies.

The third case will lead us to our next question: Consider the above-stated question from the point of view of a non-theological outsider, whether a comparative historian of religion, a historian tout court, an archaeologist, a scholar in literature, a psychologist, sociologist or anthropologist. He or she will be aware that colleagues from the theological faculty labour fields that remain untilled and unploughed in his or her own faculty. They will be ready to assume that there is much to be gained from critical interaction and interdisciplinarity. But cooperation across faculty boundaries often confirms the expectation that questions, methods and answers produced in theological discourse (regardless of which discipline is involved) differ - in ways which colleagues external to theology often find hard to define - from what they are used to in their own discipline and faculty, for better or for worse.

\section{Detrimental Side-effects of the Conjunction of Biblical Studies and Theology}

Although interdisciplinary exchange is greatly facilitated by new media technologies (for instance, access to electronically published journals regardless of physical obstacles such as discrete institute libraries), one may ask whether the tradition-honoured and characteristically European conjunction of biblical studies with theology has not also produced a number of side-effects which should be criticized on scientific and academic grounds.

The most blatant example of such a side-effect known to me is related to the so-called Konfessionsklausel applied in German and Austrian universities, according to which a biblical scholar (but this also holds for any other theological sub-discipline) applying for a faculty position must belong to the 'correct' confessional denomination. Is not this a perfectly irritating criterion which has nothing to do with intrinsically academic standards and which can lead to openly absurd situations when it comes to filling a position in, say, biblical archaeology or in History of Religion(s)? Equally unacceptable from an academic point of view is the fact that Church authorities of whatever level (whether the provincial authorities of a cantonal Church in Switzerland or officers with global authority operating in a Vatican prefecture) should participate in (be it only to confirm) the choice of faculty. Such situations undermine the academic credibility and reputation of theology and biblical studies, and they should not be tolerated in public universities whose exclusive referent must be the search for critical knowledge in an open, pluralist and democratic society.

I may add that another detrimental side-effect is, luckily, in decline: When the canons of theological disciplines and their respective Hilfswissenschaften were fixed in the nineteenth and early twentieth century, and as a result of increasing specialization and disciplinary differentiation within Faculties of Letters and Humanities, the study of biblical languages (Hebrew, Greek, often Syriac and other 'Oriental', usually Near Eastern, languages) was allotted to biblical studies wherever these existed at university level. As a result, biblical philology was somehow disconnected, by 
faculty divide, from other ancient Near Eastern philologies, but also from so-called 'Classical' (Greek and Latin) philology. Since language skills (grammar, lexicon, etc.) and comparative linguistics are fundamental to any philological discipline, scholars working in biblical and cognate philologies soon came to compensate for the divide through individual cooperation. Still, the very fact that so-called 'Biblical Hebrew' or 'New Testament Greek' is usually taught in Faculties of Theology rather than among cognate philologies in the Faculty of Letters remains an oddity.

Even more problematic, the history of Canaan/Israel/Palestine from the late second millennium to the Late Roman period has been treated for decades by biblical scholars in an enclave largely detached from general history - a situation which has been and continues to be detrimental to both sides. I do not have to recall here how difficult it was for the 'history of ancient Israel and Judah' to free itself from the biblical master narrative. Nor will I have to stress that theoretical advances in general history (Geschichtstheorie) have often taken decades and generations to be received in biblical scholarship.

Archaeology, to take an even more striking example, has long remained in Palestine/Israel an enterprise of Bible-driven scholars and institutions - many of them amateurs rather than professionals in terms of archaeological technique. 'Biblical archaeology' thus evolved largely disconnected from other Mediterranean archaeologies until only a few decades ago. If things have undoubtedly improved over the last 40 years or so, this is due to two main factors: first, the rise in Israel of secular, non-theological research institutions concerned with Israel's 'national' history and archaeology; second, the growing inclusion, within non-theological departments of history, languages and literature, of research topics that had formerly been reserved to Faculties of Theology.

Let me conclude this collection of grievances by pointing out a field where the insulation of biblical scholarship operating in theological environments can be felt drastically in another way which, from a scholarly point of view, is unsatisfactory: the special field of the history of ancient Levantine religion, which includes the religion of 'ancient Israel and Judah'. Having been involved in research in this field in my former academic position as a biblical scholar, I noticed in hindsight, having moved to Religionswissenschaft (or, more focused, History of Religions/ Comparative Religion), how relatively little mutual awareness and conversation exists between the religio-historical study of ancient Israel/Palestine in 'biblical times' and other fields of comparative religious studies, both materially and theoretically. As a result, scholarship on the history of ancient Levantine religion usually privileges ancient 'Israelite' religion more than anything else - because of theological prejudice and of its putative link to the Bible (and ultimately, to 'credal Israel'); but the very notion of what should be looked for and construed as 'religion' in 'ancient Israel' is actually more indebted to Christian, Protestant concepts of belief than to ancient material evidence; and much of this research has developed with hardly any reference to anthropological, cultural and social theory. ${ }^{11}$

11. Remarkable exceptions to the rule have been published recently, and most recent studies and syntheses are now taking care to consistently relate material data to theory. 
Crossing Borders: The Bible in the Study of Religion(s) - Systemic Ignorance?

I should not, however, put all the blame for this unfortunate situation on biblical scholars and the relative handicap of working within theological environments. As a matter of fact, the great divide between biblical studies (as practiced in privileged conjunction with theology) and the History of Religions/Comparative Religion has a detrimental effect on the latter discipline as well. All too often the History of Religions (not to speak of Religionswissenschaft in the broader sense) evidences a startling ignorance of the material sources, conceptual problems, sophisticated methods and historical hypotheses debated in contemporary critical biblical scholarship. Fairness of judgement demands that we acknowledge this ignorance to be mutual; as a matter of fact, it is detrimental to the quality of academic scholarship performed by scholars of either tribe.

The modern academic discipline called History of Religions (or 'Science of Religion' in the words of Friedrich Max Müller, himself a major representative of the Orientalist philological tradition ${ }^{12}$ ) developed through dissociation from theological Philologia Sacra, applying the latter's methods to religious writings of various 'world religions. ${ }^{13}$ Müller, the founder and general editor of a large collection of translated writings entitled Sacred Books of the East, ${ }^{14}$ had initially planned to include the Bible in his enterprise but was fiercely opposed on this project by fellow theologians.

Since its disciplinary establishment as an independent academic discipline in the late nineteenth century, the History of Religions stresses its non-theological and non-confessional character. Having been established against theology by Orientalists, History of Religions largely lost sight of the Bible, which in turn became a kind of hostage controlled by theology. It comes as no surprise that History of Religions, according to my experience, largely ignores research and recent advances in the study of 'ancient Israelite' religion, since historians of religion rarely develop specific expertise in this particular field of studies. Even more detrimental, biblical studies are sometimes wrongly suspected by practitioners of Religionswissenschaft to be confessionally inhibited per se, or the Bible to be the ultimate origin of all Christocentric and Eurocentric prejudice.

The academic labour division which keeps the Bible away from comparativists and historians of religions (and vice versa ...) seems to have gone almost unquestioned when the Religionsgeschichtliche Schule occupied a prominent position in biblical scholarship. ${ }^{15}$ While being clearly conversant with religio-historical research performed at the time in other fields of ancient studies (especially Classical Philology, Assyriology and Egyptology), this particular approach to the Bible and its re-evaluation of the 'myth of salvation' represented a rather

12. On Müller see Van den Bosch 2002.

13. Another unfortunate concept which still seems to appeal to some theologians but has long been banned from the vocabulary of the study of religion(s): see Masuzawa 2005.

14. Müller 1879-1910 (repr. 2001).

15. Note the subtitle in Lüdemann 1996. 
disputed development within theology. As far as I can see, it only marginally affected the academic community beyond theology, and its impact on the History of Religions tribe remained limited. ${ }^{16}$ Of course, one should not forget Rudolf Otto who, together with other prominent phenomenologists, marks an important intersection in the history of both theological and religio-historical scholarship. However, while Otto's legacy can still be celebrated among theologians, historians of religion have long since considered the work of Otto and other fellow phenomenologists a problem rather than a promise for their discipline.

We must recognize of course that biblical scholars, especially those specializing in the Hebrew Bible/Old Testament, have generally been most inclined among theologians, by sheer professional necessity, to deal with non-Christian and non-Jewish religion(s). They have been eager to learn about ancient Egyptian, Mesopotamian, Western Semitic or Greek and Roman religion. But their qualified interest in neighbouring fields notwithstanding, European biblical studies have continued to develop within relatively restrictive disciplinary confines.

\section{Religion in the Academy of Managers}

Academic studies in religion(s) are presently undergoing profound transformations in many countries around the globe, ${ }^{17}$ and certainly so in Western Europe. ${ }^{18}$ Transformations include attempts to relocate (confessional) theology in state-run universities and/or to redefine theology's relation to other ways of studying Christian and other religion(s). Such transformations are not always imposed on the academic community from the outside: I know of several cases where creative reorganization and realignment resulted from self-conscious initiatives on behalf of those first concerned, ${ }^{19}$ while in other situations, state or university authorities have pressed the faculties concerned toward change but still left them some marge de manoeuvre to conceive what transformation would be acceptable from their own point of view within certain parameters. More often than not, however, transformations were imposed from outside on other than scientific grounds, the basic compulsory requirement being shrinkage and budgetary reduction

16. Submission deadlines prevented me from further investigating this issue, hence this all too brief statement which is open to revision.

17. For recent overviews on the field worldwide, see Alles 2007; Casadio and Prandi 2009.

18. On the study of religion(s) in Western Europe, see the extraordinarily informative overview by Stausberg 2007; 2008; 2009.

19. For instance, the Faculty of Theology of the University of Lausanne has recently undergone profound mutations and is now the Faculty of Theology and Religious Studies. The terminological and institutional arrangement has parallels, e.g. in the Netherlands and the United Kingdom. 
in conjunction with a thorough remodelling of academia according to internationally defined European rules. ${ }^{20}$

One does not need to be a diviner to recognize one new feature in recent transformative processes, when compared to earlier reforms: economic, political and managerial considerations and arguments are today frankly outspoken, not hidden as they often used to be in the past behind an elegant veil of academic ideals, epistemological principles or moral values. There are many good reasons, from a humanistic scholar's perspective, to regret the ongoing managerial revolution in academia. But the fact that economic and managerial arguments are made crystalclear and transparent should in my view be positively valued (which is not to say that I always find them convincing). As a matter of fact, it is today considered legitimate and has become perfectly acceptable in both public and even academic discourse to state that scientific research, and the production and transmission of knowledge in state-run institutions of higher education, particularly universities, should be subjected to economic, organizational, bureaucratic, legal and political rules: that is, society-related considerations which are non-intrinsic, often unrelated and sometimes contrary to the scholarly subject matter. To use a system-theoretical terminology (loosely borrowed from sociologist Niklas Luhmann $^{21}$ ) while the peculiar rationality of science and scholarship ('Die Wissenschaft der Gesellschaft') has not yet deserted public universities, state-run public universities are today subjected to principles of governance which are obviously no longer driven by the rationality of science in the first place.

The fact that managerial power has taken over the rule should not prevent scholars from claiming that when it comes to decisions involving the critical assessment of the taxonomy of knowledge, they might know better because of their acquaintance with the subject matter, with disciplinary histories and with interdisciplinarity. However, they can no longer rely on the assumption that the models inherited from the past will go unquestioned.

\section{Societal Change and Confessional Pasts}

When seen from a distance and articulated in the most neutrally detached terms possible, the above-mentioned processes of change in academia seem linked in no small proportion to a decrease of esteem, among contemporary decisionmakers, for what academic tradition (not least in the Netherlands) used to call 'pure knowledge' and 'fundamental research', that is, research leading to knowledge which is thought to have an intrinsic value and significance and cannot be immediately applied to some useful end. In the case of research on religion(s), one may further observe a growing tendency of European and national funding agencies

20. A special issue of Religion (Engler and Stausberg 2011) is entitled 'Crisis and Creativity: Opportunities and Threats in the Global Study of Religion $\backslash$ s'. Stausberg specifically addresses 'The Bologna process and the study of religionls in (Western) Europe' (187-207).

21. Luhmann 1992. 
to favour projects with a recognizable and more or less immediate social pay-off. Such research is certainly valuable in its own terms and should be encouraged in its own right; being more akin, however, to social engineering (and hence, to the disciplining and domestication of societies increasingly pressured, e.g., by public debate on migration and multiculturalism) than to the production of meaningful knowledge as such, one should not favour it at the expense of fundamental research since the two kinds of research clearly do not fulfil the same social function and do not respond to the same academic needs. With all due respect to colleagues studying domestic religion and religion policies in the field of social sciences, it stands to reason that the scientific study of religion(s) has, over the last two or three decades, come under the increasing pressure of utilitarian, policy-oriented considerations. As a result, more traditional research aiming at an improved knowledge of ancient societies and 'dead' languages have been increasingly marginalized in academia.

Since the above-mentioned displacements in the rational foundation of research occur in most Western European countries at the same time and at a similar pace, it also partly stands to reason that it is partly driven by the political process of European integration. Academia may have been a relatively decentralized system a generation or two ago; but with central bureaucracies operating at national levels, it is nowadays ruled by technocrats applying transnational managerial standards. It is interesting, however, to observe that change has nevertheless followed quite different, distinct ways of procedure in various European countries, depending on established political, legal and even academic structures that differ considerably from one country to another. As far as theology and religious studies are concerned, processes of change are often conditioned by existing state-church arrangements, which range from close cooperation to strict separation, and to current debates concerning publicly exposed religious minorities, their place in civil society and the role they might play within public institutions.

The processes mentioned can be observed throughout Europe, but they seem to have affected countries of Protestant tradition more than traditionally Catholic countries. In most of the latter, especially in Southern Europe (but not in Germany), a clear separation of state and church had banned theology from state universities for generations. ${ }^{22}$ In contrast, many countries of Protestant tradition have long lived on state-church arrangements in which the state considered the church as an eminent guardian of public order and morality, and hence granted it considerable privileges in academia and in society at large. That theological institutes in countries with a laicized legal regime such as France or Italy seem to suffer less profound transformations today is not really surprising, since they have long been exclusively supported by their respective religious bodies anyway, with only minimal or no state involvement at all. In contrast, universities in countries where a strong Protestant tradition has long prevailed (England, Scandinavian countries, the Netherlands ... ) witness more profound challenges to and transformations of traditional institutional arrangements.

22. Again, one should not draw hasty conclusions, since Belgium presents a different case. 
When viewed from a distance in a social-historical perspective (Braudel's intermediate level of history), there is a certain irony in the fact that Protestant theological faculties in once Protestant-ruled countries, which had adapted earlier and more successfully to enlightenment ideals and liberalism than Catholic faculties, to the extent of being forerunners of enlightenment and even rationalism themselves, have today come under the heaviest pressure. That not only individuals but also the institutions directly concerned should experience the loss of their historic privileges as a kind of rejection (sometimes coming close to a sentiment of being forced into an intra-societal exile) can easily be understood even by the remote observer. Such a sentiment is clearly palpable, e.g. among Protestant faculties in Switzerland which all represent a Reformed, or Calvinist (i.e. heavily rationalist and 'secularized'), form of Christian theology.

\section{A German Sonderfall?}

Other circumstances hinting at relative stability seem to apply in Germany, where major churches and their faculties of theology still enjoy a particularly privileged situation buttressed by fundamental state law. Interestingly enough, the questioning of historic privileges thus takes a different trajectory in Germany: Instead of Catholic or Protestant denominational faculties of theology being pressured or suppressed, Jewish and Muslim collectivities invoke constitutional rights in order to obtain similar rights and establish new faculties or institutes of Jewish or Islamic theology. Supported by the German Wissenschaftsrat, this claim has led to the consolidation or establishment of a Jewish Faculty of Theology at Potsdam, and of Institutes of Islamic theology at several universities (Erlangen, Frankfurt, Hamburg, Münster, Tübingen ...). This development in Germany is contrary to what happens in most other European countries, where state authorities tend rather to disenfranchise themselves from historic obligations towards churches and confessional theologies, and it is arguably motivated more by political interests and social engineering processes than by academic, let alone scientific, reasons.

From a European perspective, the institutional status and organizational arrangements of Christian theology in Germany represent a kind of Sonderfall: Faculties of Theology enjoy a special protection by constitutional law and operate on the basis of special contractual obligations and commitments between the Federal State and the major national Churches. I will not go into the problematic history of this arrangement, but viewed from the outside, this regime which seems to be almost immune to organizational innovation looks so peculiar that it cannot per se provide a model for other European countries. Nor should it, in my view, be regarded as a model in the first place. This is a regime which anachronistically sanctifies social exceptionalism and protectionism of Christian religion and theology in a way that openly contradicts the values of modern, pluralistic democracies and finds itself in regular tension with intrinsically scientific and academic standards. 
Interestingly enough, it is in Germany where such historic privileges subsist (but for how long?), preserving academic theologies in a protectionist environment, that the discourse about a fundamental incompatibility of theology vs. the non-confessional study of religion(s) remains the most vivid and often takes a quite polemical tone. Such polemics are not without a fundamentum in $r e$, since protectionist interests and attitudes have as a matter of fact, under those particular German circumstances, prevented the self-composed development of non-confessional studies of religion(s), a development that seems to be called for by growing pluralism and would certainly be in tune with a profoundly changed place of religion in present-day societies, in Germany as much as in other European countries.

Turning to biblical scholarship, I do not question the fact that German scholars have long played (and some continue to play) a leading role in international biblical research. But a constitutionally privileged system does not produce highquality results per se and quasi-automatically, and there is no guarantee that it will continue to do so under currently changing social, political, economic and (perhaps) legal circumstances. When viewed from a distance, German biblical scholarship currently benefits from an unbalanced protectionist regime. Needless to say, such a regime does not invite young scholars interested in the comparative History of Religions to invest their future in biblical studies, as long as the latter are exclusively linked to Faculties of Theology. It is hard to predict how long this peculiar regime will endure; but people in charge of universities in other countries should not consider German exceptionalism as a model for future policy-making.

Can we learn from the German Sonderfall in a way that will not take it as a model but as an example of institutional arrangements that should not be followed in the future?

\section{Who will Care for Critical, Academic Biblical Studies in the Future?}

Who then, we may ask, will care for (and take care of) the critical, academic study of the Bible and of 'ancient Israelite' religion in European state-run universities if theology comes increasingly under pressure? I wonder whether the potential of a 'strategic alliance' of sorts between biblical studies and the non-confessional study of religion(s) has been sufficiently explored in recent discussions and organizational realignments. ${ }^{23}$ Such an alliance would bring together two new 'partners' who do not have much experience in common academic endeavours but are rather used to keeping distance between each other. An alliance would probably require major intellectual moves on behalf of both partners: on the one hand, the recognition by biblical scholars that their traditional close relationship to theology may be a feature that, in state-run universities, belongs to the past, and that they have much to gain from academic cooperation with the non-confessional study of

23. Such an alliance, in some form or other, seems already to have been taking place in many UK universities over the past two or three decades. 
religion $(\mathrm{s}) .{ }^{24}$ On the other hand, History of Religions will have to recognize its own blind spots, which are as I suggested a project of past alignments and processes of disciplinary consolidation. In my personal view and experience, ignorance of biblical studies and of current research in the history of 'ancient Israelite' religion is a major blind spot in the History of Religions as practised today in European countries. It may well be that if either side is ready to acknowledge its blind spots and deficiencies, and the detrimental effects of past organizational alignments and epistemic solidarities on the disciplines concerned, another future might be considered which would be one of partnership rather than dissociation.

I am personally convinced that an open, liberal and democratic, pluralist and multicultural society must preserve an intellectual space (and hence, some spare resources) for critical, academic research on ancient Near Eastern, Mediterranean, Jewish, Christian, Manichaean and other religions' connected and entangled histories. Such research may be performed by theologians where no secular alternative is at hand, but the open society should also reserve more space for the non-confessional study of religion(s). This being stated, it will probably belong to another generation of scholars to discuss the terms of such a new partnership. The best that our generation can offer them in the process is open-mindedness.

24. Colleagues from biblical studies regularly claim that what they are doing is not any different from a historian of religion's work. But I do not encounter them at international meetings of professional historians of religion. Is not that one aspect of the problem? 


\section{BIBLIOGRAPHY}

Aalen, S. (1951), Die Begriffe 'Licht' und 'Finsternis' im Alten Testament, im Spätjudentum und im Rabbinismus (Oslo: Jacob Dybwad).

-(1972), 'רוא, 'ôr', in G. J. Botterweck and H. Ringgren (eds), Theologisches

Wörterbuch zum Alten Testament, vol. 1 (Stuttgart: Kohlhammer), 160-82 = ET,

Theological Dictionary of the Old Testament, vol. 1 (Grand Rapids: Eerdmans, 1974), 147-67.

Achenbach, Reinhard (2003), Die Vollendung der Tora: Studien zur Redaktionsgeschichte des Numeribuches im Kontext von Hexateuch und Pentateuch (BZAR 3; Wiesbaden: Harrassowitz).

—(2009), 'Verunreinigung durch die Berührung Toter. Zum Ursprung einer altisraelitischen Vorstellung', in Angelika Berlejung and Bernd Janowski (eds), Tod und Jenseits im alten Israel und seiner Umwelt (FAT 64; Tübingen: Mohr Siebeck), $347-69$.

Aharoni, Yohanan (1967), The Land of the Bible: A Historic Geography, trans. Anson F. Rainey (London: Burns and Oates).

-(1979), The Land of the Bible: A Historical Geography, 2nd rev. edn (London: Burns \& Oates).

Aharoni, Yohanan and Michael Avi-Yonah (1968, 1973), The MacMillan Bible Atlas (New York, London: Macmillan Publishers).

Ahituv, Shmuel (2008), Canaanite Toponyms in Ancient Egyptian Documents (Jerusalem: Magnes Press; Leiden: Brill).

-(2008), Echoes from the Past: Hebrew and Cognate Inscriptions from the Biblical Period (Jerusalem: Carta).

Akhmatova, Anna (1973), 'Lot's Wife', in Stanley Kunitz (ed.), Poems of Akhmatova (Boston: Little, Brown \& Co.).

Albertz, Rainer (1986), 'Review of Blum, Erhard: Die Komposition der Vätergeschichte', Theologische Literaturzeitung 111: 180-3.

-(1994), A History of Israelite Religion in the Old Testament Period, 2 vols (London: SCM); ET of Geschichte der israelitischen Religion, 2 vols (Das Alte Testament Deutsch Ergänzungsreihe 8; Göttingen: Vandenhoeck \& Ruprecht, 1992).

-(2011a), 'Das Buch Numeri jenseits der Quellentheorie: Eine Redaktionsgeschichte von Num. 20-24', ZAW 123: 171-83, 336-47.

-(2011b), 'Ex 33,7-11, ein Schlüsseltext für die Rekonstruktion der Redaktionsgeschichte des Pentateuch', BN 149: 13-43.

-(2011c), 'The Controversy about Judeans versus Israelite Identity and the Persian Govnernment: A New Interpretation of the Bagoses Story (Jewish Antiquities XI.297301)', in Oded Lipschits, Gary N. Knoppers and Manfred Oeming (eds), Judah and the Judeans in the Achaemenid Period: Negotiating Identity in an International Context (Winona Lake, IN: Eisenbrauns), 483-504.

-(2011d), 'The Late Exilic Book of Exodus (Exodus 1-34*): A Contribution to the Pentateuchal Discussion', in Thomas B. Dozeman, Konrad Schmid and Baruch J. 
Schwartz (eds), The Pentateuch: International Perspectives on Current Research (FAT 78; Tübingen: Mohr Siebeck), 243-56.

-(2012), Exodus, Band I: Ex 1-18 (ZBK.AT 2.1; Zürich: Theologischer Verlag Zürich).

- (2013), 'A Pentateuchal Redaction in the Book of Numbers? The Late Priestly Layers of Num. 25-36', Zeitschrift für die alttestamentliche Wissenschaft 125: 220-33.

Albertz, Rainer and Bob Becking (eds) (2003), Yahwism after the Exile: Perspectives on Israelite Religion in the Persian Era (STAR 5; Leiden: Brill).

Albright, William F. (1957), 'The High Place in Ancient Palestine', in Volume du Congrès Strasbourg 1956 (VTSup 4; Leiden: Brill), 242-58.

Alexander, Philip S. (1988), 'Jewish Aramaic Translations of Hebrew Scriptures', in M. J. Mulder (ed.), Mikra: Text, Translation, Reading and Interpretation of the Hebrew Bible in Ancient Judaism and Early Christianity (CRINT II/1; Assen: Van Gorcum), $217-53$.

Allen, Leslie (2008), Jeremiah (OTL; Louisville, KY and London: Westminster John Knox Press).

Alles, Gregory (ed.) (2007), Religious Studies: A Global View (London: Routledge).

Alster, Bendt (1999), 'Tiamat', in Karel van der Toorn et al. (eds), Dictionary of Deities and Demons in the Bible, 2nd edn (Leiden/Grand Rapids: Brill/Eerdmans), 867-9.

Andersen, Francis and David Noel Freedman (2000), Micah: A New Translation and Commentary (AncB 24E; New York: Random House).

Annus, Amar and Alan Lenzi (2010), Ludlul Bèl Nèmeqi: The Standard Babylonian Poem of the Righteous Sufferer (SAA Cuneiform Texts VII; Winona Lake: Eisenbrauns).

Arnaud, Daniel (2004), Nabuchodonosor II: Roi de Babylone (Paris: Fayard).

Arneth, Martin (2002), 'Psalm 72 in seinem altorientalischen Kontexten', in Eckart Otto and Erich Zenger (eds), "Mein Sohn bist du" (Ps. 2,7): Studien zu den Königspsalmen (SBS 192; Stuttgart: Katholisches Bibelwerk), 135-72.

Assmann, Jan (2000), Religion und das kulturelle Gedächtnis (München: Beck).

-(2006), Religion and Cultural Memory (Cultural Memory in the Present; Stanford: Stanford University Press).

Aster, Shawn Z. (2012), The Unbeatable Light: Melammu and Its Biblical Parallels (AOAT 384; Münster: Ugarit-Verlag).

Astour, Michael C. (1965), Hellenosemitica: An Ethnic and Cultural Study in West Semitic Impact on Mycenaean Greece (Leiden: Brill).

Avigad, Nahman (1986), Hebrew Bullae from the Time of Jeremiah: Remnants of a Burnt Archive (Jerusalem: Israel Exploration Society).

—(1997), Corpus of West Semitic Stamp Seals, ed. B. Sass (Jerusalem: The Israel Academy of Sciences and Humanities).

Baentsch, Bruno (1903), Exodus - Leviticus - Numeri (Handkommentar zum Alten Testament I/2; Göttingen: Vandenhoeck \& Ruprecht).

Balabanlilar, Lisa (2012), Imperial Identity in the Mughal Empire: Memory and Dynastic Politics in Early Modern South and Central Asia (Library of South Asian History and Culture 1; London: Palgrave Macmillan).

Balla, Ibolya (2011), Ben Sira on Family, Gender, and Sexuality (DCLS 8; Berlin: De Gruyter). Baly, Denis (1957), The Geography of the Bible (London: Lutterworth).

Barkay, Gabriel ( 1994), 'A Second "Governor of the City" Bulla', in Hillel Geva and Joseph Shedur (eds), Ancient Jerusalem Revealed (Jerusalem: Israel Exploration Society), 141-44.

Barkay, Gabriel and Andrew G. Vaughn (2004), 'Hebrew Inscriptions, Section C: The Royal and Official Seal Impressions from Lachish', in David Ussishkin (ed.), The 
Renewed Archaeological Excavations at Lachish (1973-1994) (Tel Aviv: Tell Aviv University), 2148-73.

Barnard, Henk (1987), Bijbel voor de jeugd: Oude Testament, Vol. 2 (Houten: Van Holkema \& Warendorf).

Barr, James (1961), The Semantics of Biblical Language (Oxford: Oxford University Press).

Barstad, Hans M. (1983), The Religious Polemics of Amos: Studies in the Preaching of Am 2, 7B-8; 4,1-13; 5,1-27; 6, 4-7; 8, 14 (VTSup 34; Leiden: Brill).

-(1996), The Myth of the Empty Land: A Study of the History and Archaeology of Judah During the 'Exilic' Period (Symbolae osloenses fasc. suppl. 28; Oslo: Scandinavian University Press).

-(2008), History and the Hebrew Bible: Studies in Ancient Israelite and Ancient Near Eastern Historiography (FAT 61; Tübingen: Mohr Siebeck).

-(2012), 'Jeremiah the Historian: The Book of Jeremiah as a Source for the History of the Near East in the Time of Nebuchadnezzar', in Geoffey Khan and Diana Lipton (eds), Studies in the Text and Versions of the Hebrew Bible in Honour of Robert Gordon (VTSup 149; Leiden: Brill), 87-98.

Barth, Hermann (1977), Die Jesaja-Worte in der Josiazeit: Israel und Assur als Thema einer produktiven Neuinterpretation der Jesajaüberlieferung (WMANT 48; NeukirchenVluyn: Neukirchener Verlag).

Barthélemy, Dominique (1992), Critique textuelle de l'Ancient Testament. Tome 3. Ezéchiel, Daniel et les 12 Prophètes (OBO 50/3; Fribourg: Editions universitaires; Göttingen: Vandenhoeck \& Ruprecht).

Barthes, Roland (1977), 'The Death of the Author', in Roland Barthes, Image - Music Text, ed. and trans. Stephen Heath (New York: Hill and Wang), 142-8.

Bauer, Hans and Pontus Leander (1927), Grammatik des Biblisch-Aramäischen (Halle/ Saale: Max Niemeyer; reprinted Hildesheim: Olms, 1995).

Baumgartner, Walter (1944), 'Israelitisch-Griechische Sagenbeziehungen', Schweizerisches Archiv für Volkskunde 41: 1-29; reprinted in his Zum Alten Testament und seiner Umwelt (Leiden: Brill, 1959), 147-78.

Bayliss, Miranda (1973), 'The Cult of Dead King in Assyria and Babylonia', Iraq 35: $115-25$.

BdA (2007), Casevitz, Michel, Cécile Dogniez and Marguerite Harl, Les Douze Prophètes 10-11, Aggée, Zacharie (BdA 23.10-11; Paris: Editions du Cerf).

Beaulieu, Paul-Alain (1989), The Reign of Nabonidus King of Babylon 556-539B.C. (Yale Near Eastern Researches 10; New Haven: Yale University Press).

Becher, Tony and Paul R. Trowler (2001), Academic Tribes and Territories: Intellectual Enquiry and the Cultures of Disciplines, 2nd edn (Buckingham: Open University Press).

Becker, Uwe (2008), 'Psalm 72 und der Alte Orient: Grenzen und Chancen eines Vergleichs', in Angelika Berlejung and Raik Heckl (eds), Mensch und König: Studien zur Anthropologie des Alten Testaments (Fs R. Lux; Herders Biblische Studien 53; Freiburg: Herder), 123-40.

Becking, Bob (1981/1982), 'The Two Neo-Assyrian Documents from Gezer in their Historical Context', Jaarbericht Ex Oriente Lux 27: 76-89.

-(1990), 'Iphigeneia in Gilead, over het verstaan van Richteren 11, 29-40', Kerk en Theologie 41: 193-205.

-(1992), The Fall of Samaria: An Historical and Archaeological Study (SHANE 2; Leiden: Brill). 
-(1997), 'Assyrian Evidence for Iconic Polytheism in Ancient Israel?', in Van der Toorn, $157-71$

-(2001), 'The Hellenistic Period and Ancient Israel: Three Preliminary Statements', in Lester L. Grabbe (ed.), Did Moses Speak Attic? Jewish Historiography and Scripture in the Hellenistic Period (Sheffield: Sheffield Academic Press), 78-90.

-(2002), 'The Exile Does Not Equal the Eschaton: An Interpretation of Micah 4:1-5', in Ferenc Postma et al. (eds), The New Things: Eschatology in Old Testament Prophecy (Fs for Henk Leene; Maastricht: Shaker), 1-7.

-(2006), "We All Returned as One!": Critical Notes on the Myth of the Mass Return', in Oded Lipschits and Manfred Oeming (eds), 3-18.

-(2007), From David to Gedaliah: The Book of Kings as Story and History (OBO 228; Fribourg: Academic Press).

-(2008), 'The Enigmatic Garden of Uzza: A Religio-Historical Footnote to 2 Kings 21:18, 26', in I. Kottsieper et al. (eds), Berührungspunkte. Studien zur Sozial- und Religionsgeschichte Israels und seiner Umwelt: Festschrift für Rainer Albertz zu seinem 65. Geburtstag (AOAT 350; Münster: Ugarit-Verlag), 383-490.

-(2009), 'On the Identity of the "Foreign" Women in Ezra 9-10', in Lester L. Grabbe and Gary N. Knoppers (eds), Exile and Restoration Revisited: Essays on the Babylonian and Persian Period in Memory of Peter R. Ackroyd (Library of Second Temple Studies; London, New York: T\&T Clark), 31-49.

-(2009), 'The Boundaries of Israelite Monotheism', in Anne-Marie Korte and Maaike de Haardt (eds), The Boundaries of Monotheism: Interdisciplinary Explorations into the Foundations of Western Monotheism (STAR 13; Leiden: Brill), 9-27.

-(2011), 'Yehudite Identity in Elephantine', in Oded Lipschits, Gary N. Knoppers and Manfred Oeming (eds), 403-18.

-(2011), Ezra, Nehemiah, and the Construction of Early Jewish Identity (FAT 80; Tübingen: Mohr Siebeck).

-(2012), 'Global Warming and the Babylonian Exile', in John Ahn and Jill Middlemas (eds), By the Irrigation Canals of Babylon: Approaches to the Study of the Exile (LHBOTS 526; London: T \& T Clark), 49-62.

-(2013), 'Micah in Neo-Assyrian Light', in R. P. Gordon and H. M. Barstad (eds), “Thus Speaks Ishtar of Arbela": Prophecy in Israel, Assyria, and Egypt in the Neo-Assyrian Period (Winona Lake: Eisenbrauns), 111-28.

Becking, Bob and Marjo C. A. Korpel (eds) (1999), The Crisis of Israelite Religion: Transformation of Religious Tradition in Exilic and Post-Exilic Times (OTS 42; Leiden: Brill).

Beentjes, Pancratius C. (1981), Jesus Sirach en Tenach: Een onderzoek naar en een classificatie van parallellen, met bijzondere aandacht voor hun functie in Sirach 45:6-26 (Nieuwegein: privately published).

-(1996), 'Discovering a New Path of Intertextuality: Inverted Quotations and Their Dynamics', in Lénart J. de Regt, Jan de Waard and Jan P. Fokkelman (eds), Literary Structure and Rhetorical Strategies in the Hebrew Bible (Assen: Van Gorcum), $31-50$.

-(2000), 'Canon and Scripture in the Book of Ben Sira', in Magne Sæbø, (ed.), Hebrew Bible / Old Testament: The History of Its Interpretation (Vol. I, Part 2 - The Middle Ages; Göttingen: Vandenhoeck \& Ruprecht), 591-605.

- (2009), 'Portrayals of David in Deuterocanonical and Cognate Literature', in Hermann Lichtenberger and Ulrike Mittmann-Richert (eds), Biblical Figures in Deuterocanonical and Cognate Literature (DCLY 2008; Berlin: De Gruyter), 165-81. 
-(2011), 'Reconstructions and Retroversions: Chances and Challenges to the Hebrew Ben Sira Text', in Jean-Sebastien Rey and Jan Joosten (eds), The Texts and Versions of the Book of Ben Sira: Transmission and Interpretation (JSJS 150; Leiden: Brill), 23-35.

-(2013), “'Come to me, you who desire me ..." - Lady Wisdom's Invitation in Ben Sira 24:19-22', in Renate Egger-Wenzel, Karin Schöpflin and Johannes F. Diehl (eds), Weisheit als Lebensgrundlage. Festschrift für Friedrich V.Reiterer (DCLS 15; Berlin: De Gruyter), 1-11.

Ben Dov, Meir (1982), The Dig at the Temple Mount [Hebrew] (Jerusalem: Keter).

Ben Simeon (pseudonym) (1926a), 'De Bijbel naverteld, XIII: Joseph in Egypte (Genesis 43-45)', De Vrijdagavond 2/45: 301-2.

-(1926b), 'De Bijbel naverteld, XIV: Jacob en Joseph (Genesis 45-50)', De Vrijdagavond 2/46: 318-19.

Ben Zvi, Ehud (2003), 'What is New in Yehud? Some Considerations', in Albertz and Becking (eds), 32-48.

Bennema, Cornelis (2009), Encountering Jesus: Character Studies in the Gospel of John (Milton Keynes: Paternoster).

Berner, Christoph (2010), Die Exoduserzählung: Das literarische Werden einer Ursprungslegende Israels (Forschungen zum Alten Testament 73; Tübingen: Mohr Siebeck).

Bernier, Jonathan (2013), Aposunagogos and the Historical Jesus in John: Rethinking the Historicity of the Johannine Expulsion Passages (BibInt Ser. 122; Leiden: Brill).

Berquist, Jon L. (2006), 'Constructions of Identity in Postcolonial Yehud', in Oded Lipschits and Manfred Oeming (eds), 53-66.

Beuken, Willem A. M. (2007), Jesaja 13-27 (HThK.AT; Freiburg: Herder).

Bieberstein, Klaus and Hanswulf Bloedhorn (1994), Jerusalem: Grundzüge der Baugeschichte vom Chalkolithikum bis zur Frühzeit der osmanischen Herrschaft 3 (BTAVO B 100/3; Wiesbaden: Dr. Ludwig Reichert Verlag).

Bienkowski, Piotr (ed.) (1991), The Art of Jordan: Treasures from an Ancient Land (Merseyside: Alan Sutton).

Bienkowski, Piotr and Eveline J. van der Steen (2001), 'Tribes, Trade and Towns: A New Framework for the Late Iron Age in Southern Jordan and the Negev', BASOR 323: $21-47$.

Bijbelsch magazijn (1842), Bijbelsch magazijn voor alle standen ter verspreiding en bevordering van kennis der Heilige Schrift, vol. I/1 (Amsterdam: Portielje).

Bliss, Fredrick J. and Robert A. S. Macalister (1902), Excavations in Palestine 1898-1900 (London: The Committee of the Palestine Exploration Fund).

Bloch, Ernst (1968), Atheismus im Christentum: Zur Religion des Exodus und des Reichs (Frankfurt: Suhrkamp).

Bloch-Smith, Elizabeth and Beth Alpert Nakhai (1999), 'A Landscape Comes to Life: The Iron I Period,' Near Eastern Archaeology 62: 62-92, 102-27.

Blum, Erhard (1984), Die Komposition der Vätergeschichte (WMANT 57; NeukirchenVluyn: Neukirchener Verlag).

-(1990), Studien zur Komposition des Pentateuch (BZAW 189; Berlin and New York: Walter de Gruyter).

-(2002), 'Die literarische Verbindung von Erzvätern und Exodus: Ein Gespräch mit neueren Endredaktionshypothesen', in Jan Christian Gertz, Konrad Schmid and Markus Witte (eds), Abschied vom Jahwisten: Die Komposition des Hexateuch in der jüngsten Diskussion (BZAW 315; Berlin and New York: Walter de Gruyter), 117-56. 
-(2010), 'Der kompositionelle Knoten am Übergang von Josua zu Richter: Ein Entflechtungsvorschlag, in Erhard Blum, Textgestalt und Komposition: Exegetische Beiträge zu Tora und Vordere Propheten (FAT 69; Tübingen: Mohr Siebeck), 249-58.

Boman, Thorleif (1954), Das hebräische Denken im Vergleich mit dem Griechischen (Göttingen: Vandenhoeck \& Ruprecht).

Bonatz, Dominik (2000), Das syro-hethitische Grabdenkmal (Mainz: Von Zabern).

Bongenaar, Herman (Arminius Cornelius Valentinus Maria) and Ben J. J. Haring (1994), 'Egyptians in Neo-Babylonian Sippar', JCS 46: 59-72.

Bordreuil, Pierre and Pardee Dennis (1990), 'Le papyrus du marzeah', Semitica 38: 49-68.

Borstel, L. s.a. (1884), De Bijbel, schetsen en tafereelen voor Israëlietische huisgezinnen (Leiden: A. W. Sijthoff).

Bosch, Lourens P. van den (2002), Friedrich Max Müller: A Life Devoted to the Humanities (Numen 94; Leiden: Brill).

Boyd-Taylor, Cameron (2011), Reading between the Lines: the Interlinear Paradigm for Septuagint Studies (BTS 8; Leuven: Peeters).

Braun, Rainer (1973), Kohelet und die frühhellenistische Popularphilosophie (BZAW 130; Berlin: De Gruyter).

Brenner, Athalya (1999), 'Ruth as a Foreign Worker and the Politics of Exogamy', in Athalya Brenner (ed.), Feminist Companion to Ruth and Esther (Sheffield: Sheffield Academic Press), 158-62.

-(2013), 'Ruth: The Art of Memorizing Past Enemies, Ambiguously', in Ehud Ben Zvi and Diana Edelman (eds), Remembering Biblical Figures in the Late Persian and Early Hellenistic Periods. Social Memory and Imagination (Oxford: Oxford University Press), 306-10.

Briant, Pierre (1996), Histoire de l'Empire perse de Cyrus à Alexandre (Paris: Fayard).

Briffard, Colette (2002), 'Gammes sur l'Acte de traduite', Foi et Vie 101: 12-18.

Bright, John (1965), Jeremiah (AncB; Garden City, NY: Doubleday).

Broshi, Magen (1993), 'Judeideh, Tell', in Ephraim Stern (ed.), The New Encyclopedia of Archaeological Excavations in the Holy Land, vol. 3 (Jerusalem: The Israel Exploration Socienty and Carta), 837-8.

Brown, Cheryl Anne (1992), No Longer Be Silent: First Century Jewish Portraits of Biblical Women (Louisville: Westminster/John Knox).

Brown, John Pairman (1995), Israel und Hellas (BZAW 231; Berlin: De Gruyter).

-(2000), Israel and Hellas. Volume II: Sacred Institutions with Roman Counterparts (BZAW 276; Berlin: De Gruyter).

-(2001), Israel and Hellas. Volume III: The Legacy of Iranian Imperialism and the Individual (BZAW 299; Berlin: De Gruyter).

-(2003), Ancient Israel and Ancient Greece: Religion, Politics, and Culture (Minneapolis: Fortress Press).

Brown, W. (ed.) (2009), Is Critique Secular? Blasphemy, Injury, and Free Speech (Townsend Papers in the Humanities, Berkeley: The Townsend Center for the Humanities).

Brueggemann, Walter (1997), Theology of the Old Testament: Testimony, Dispute, Advocacy (Minneapolis: Fortress Press).

-(1998), A Commentary on Jeremiah: Exile and Homecoming (Grand Rapids, MI: Eerdmans).

Buber, Martin (1950), Der Glaube der Propheten (Zürich: Manesse).

Buitenwerf, Rieuwerd (2003), Book III of the Sibylline Oracles and its Social Setting: With an Introduction, Translation, and Commentary (SVTP 17; Leiden: Brill). 
Bunimovitz, Shlomo (1994), 'Socio-political Transformations in the Central Hill Country in the Late Bronze-Iron Age Transition', in Israel Finkelstein and Nadav Na'aman (eds), From Nomadism to Monarchy: Archaeological and Historical Aspects of Early Israel (Jerusalem: IES), 179-202.

Bunimovitz, Shlomo and Zvi Lederman (2009), 'The Archaeology of Border Communities: Renewed Excavations at Tel Beth- Shemesh, Part 1: The Iron Age', Near Eastern Archaeology 72: 114-42.

Burkert, Walter (1991), 'Oriental Symposia: Contrasts and Parallels', in William J. Slater (ed.), Dining in a Classical Context (Ann Arbor: University of Michigan), 7-24.

-(2003), Die Griechen und der Orient: Von Homer bis zu den Magiern (München: C. H. Beck).

Busche, Hubertus (1992), 'Religiöse Religionskritik beim frühen Hegel und beim späten Nietzsche', in Mihailo Djurič and Josef Simon (eds), Nietzsche und Hegel (Würzburg: Königshausen \& Neumann), 90-109.

Busse, Ulrich (1990), 'Metaphorik in neutestamentlichen Wundergeschichten? Mk 1,21-28; Joh 9,1-41', in Karl Kertelge (ed.), Metaphorik und Mythos im Neuen Testament (QD 126; Freiburg: Herder), 110-34.

Butler, Judith (2009), 'The Sensibility of Critique: Response to Asad and Mahmood', in Talal Assad et al. (eds), Is Critique Secular? Blasphemy, Injury, and Free Speech (Townsend Papers in the Humanities; Berkeley: The Townsend Center for the Humanities), 101-36.

Cagnazzi, Silvana (2001), Gli esili in Persia (Documenti e studi. Collana del Dipartimento di Scienze dell'antichità dell'Università di Bari; Sezione storica 29; Bari: Edipuglia).

Calduch-Benages, Nuria (1999), 'Aromas, Fragancias y Perfumas en el Sirácida', in N. Calduch-Benages and J. Vermeylen (eds), Treasures of Wisdom. Studies in Ben Sira and the Book of Wisdom (BETL 143; Louvain: Peeters), 15-30.

Callot, Olivier (2011), Les sanctuaires de l'Acropole d'Ougarit: Les temples de Baal et de Dagan (RSOu XIX; Lyon: Maison de l'Orient et de la Méditerranée).

Cameron, Averil (2014), Byzantine Matters (Princeton, NJ: Princeton University Press).

Camp, Claudia V. (2015), 'Home of the Mother, Exile of the Father: Gender and Space in the Construction of Biblical Identity', in Bob Becking, Lucien van Liere and Anne-Marie Korte (eds), Contesting Religious Identities (Leiden: Brill) (forthcoming).

Carr, David (2011), The Formation of the Hebrew Bible: A New Reconstruction (Oxford: Oxford University Press).

Carroll, Robert P (1986), Jeremiah: A Commentary (OTL; London: SCM).

-(1988), Jeremiah (Interpretation; Atlanta, GA: John Knox Press).

Casadio, Giovanni and Carlo Prandi (eds) (2009), Le scienze delle religioni nel mondo (Humanitas 1; Brescia: Morcelliana).

Cassin, Elena (1968), La splendeur divine: introduction à l'étude de la mentalité mésopotamienne (Paris: Mouton \& Co.).

Cataldo, Jeremiah W. (2009), A Theocratic Yehud? Issues of Government in a Persian Province (LHBOTS 498; New York: Bloomsbury).

-(2014), Breaking Monotheism Yehud and the Material Formation of Monotheistic Identity (2nd edn, LHBOTS, 565; New York: Bloomsbury).

Chesterman, Andrew (2000), 'A Causal Model for Translation Studies', in Maeve Olohan (ed.), Intercultural Faultness: Research Models in Translation Studies I - Textual and Cognitive Aspects (Manchester: St. Jerome), 15-27.

Clements, Ronald E. (1980), Isaiah 1-39 (NCB; Grand Rapids: Eerdmans; and London: Marshall, Morgan \& Scott). 
Clines, David J. A. (2011), Job 38-42 (WBC. 18B; Nashville: Thomas Nelson).

Cogan, Mordechai (2001), 'Sennacherib's Siege of Jerusalem: Once or Twice', BAR 27/1: $40-5,69$.

Cogan, Mordechai and Hayim Tadmor (1988), II Kings: A New Translation with Introduction and Commentary (AncB 11; New York: Doubleday).

-(2008), The Raging Torrent: Historical Inscriptions from Assyria and Babylonia Relating to Ancient Israel (Carta Handbook; Jerusalem: Carta).

Collins, John J. (2010), 'Prophecy and History in the Pesharim', in Mladen Popović (ed.), Authoritative Scriptures in Ancient Judaism (JSJSup 141; Leiden: Brill), 209-27.

Cook, Johann and Arie van der Kooij (2012), Law, Prophets, and Wisdom. On the Provenance of Translators and their Books in the Septuagint Version (CBET 68; Leuven: Peeters)

Corley, Jeremy (2002), Ben Sira's Teaching on Friendship (BJS 316; Providence: Brown University).

Cotelle-Michel, Laurence (2004), Les Sarcophages en Terre Cuite en Égypte et en Nubie de lépoque prédynastique à lépoque romaine (Dijon: Editions Faton).

Cramer-Schaap, D. A. (1957), Bijbelse verhalen voor jonge kinderen (Amsterdam: Ploegsma).

Cross, Frank M. (1970), 'The Cave Inscriptions from Khirbet Beit Lei', in James A. Sanders (ed.), Near Eastern Archaeology in the Twentieth Century (Fs Nelson Glueck; New York: Doubleday), 296-306.

-(1996), 'A Papyrus Recording a Divine Legal Decision and the Root rhq in Biblical and Near Eastern Legal Usage', in Michael V. Fox et al. (eds), Texts, Temples, and Traditions: A Tribute to Menahem Haran (Winona Lake: Eisenbrauns), 311-20.

Dahood, Mitchell (1971), 'Additional Notes on the mrzh Text', in Loren R. Fisher (ed.), The Claremont Ras Shamra Tablets (Rome: Pontificium Insttitutum Biblicum), $50-4$.

Dalley, Stephanie (2004), 'Recent Evidence from Assyrian Sources for Judahite History from Uzziah to Manasseh', JSOT 28: 387-401.

-(2008), 'Babylon as a Name for Other Cities Including Nineveh', in Robert D. Biggs et al. (eds), Proceedings of the 51st Rencontre Assyriologique Internationale Held at The Oriental Institute of the University of Chicago, July 18-22, 2005 (Studies in Ancient Oriental Civilization 62; Chicago: The Oriental Institute), 25-33.

Darby, Erin D. (2014), Interpreting Judean Pillar Figurines: Gender and Empire in Judean Apotropaic Ritual (FAT-II 69; Tübingen: Mohr Siebeck).

Darnell, John Coleman and Richard Jasnow (1993), 'On the Moabite Inscriptions of Ramesses II at Luxor Temple', JNES 52: 263-74.

Delitzsch, Franz (1889), Commentar über das Buch Jesaja (BCAT III/1; Leipzig: Dörffling \& Franke, 4. Aufl.)

Delitzsch, Friedrich (1902), Das Buch Hiob (Leipzig: J. C. Hinrichs).

Dell, Katharine J. (2005), 'Does the Song of Songs Have Any Connections to Wisdom?', in Anselm C. Hagedorn (ed.), Perspectives on the Song of Songs / Perspektiven der Hoheliedauslegung (BZAW 346; Berlin: De Gruyter), 8-26.

Deurloo, Karel and Kees van Duin (1996), Beter dan zeven zonen: De feestrol Ruth als messiaanse verwijzing (Baarn: ten Have).

Deutsch, Robert (2002), 'Lasting Impressions: New Bullae Reveal Egyptian-Style Emblems on Judah's Royal Seals', BAR 28/4: 42-51, 60-1.

-(2003a), Biblical Period Hebrew Bullae: The Josef Chaim Kaufman Collection (Tel Aviv: Archaeological Center Publications). 
- (2003b), 'A Hoard of Fifty Hebrew Clay Bullae from the Time of Hezekiah', in Robert Deutsch (ed.), Sholomo: Studies in Epigraphy, Iconography, History and Archaeology (Fs S. Moussaieff; Tel Aviv: Archaeological Center Publications), 45-98.

-(2004), 'Two Personal Hebrew Seals', in Michael Heltzer and Meir Malul (eds), Sשורות לאבישור Studies in the Bible and the Ancient Near East, in Hebrew and Semitic Languages (Fs Y. Avishur; Tel Aviv: Archaeological Center Publications), $25^{*}-28^{*}$.

Deutsch, Robert and André Lemaire (2000), Biblical Period Personal Seals in the Shlomo Moussaieff Collection (Tel Aviv: Archaeological Center Publications).

Dever, William G. (1990), 'Archaeology and Israelite Origins: Review Article', BASOR 279: 89-95.

Dhorme, Edouard (1984), A Commentary on the Book of Job (Nashville: Thomas Nelson Publishers; French original: 1926).

Di Lella, Alexander A. (1966), The Hebrew Text of Sirach: A Text-Critical and Historical Study (Studies in Classical Literature 1; The Hague: Mouton).

Dietrich, Manfried and Oswald Loretz (1981), 'Die Inschrift der Statue des Königs Idrimi von Alalah', UF 13: 201-69.

-(1982), 'Der Vertrag eines mrzh-Klubs in Ugarit: Zum Verständnis von KTU 3.9', UF 14: 71-6.

-(2005), 'Vier graphische Besonderheiten im Marzihu-Text KTU 3.9', UF 37: 221-26.

-(2005), "Weihen" ( 'ly Š) von pgr, Ochsen und Gegenständen in KTU 6.13, 6.14 und 6.62', UF 37: 227-39.

Dietrich, Walter (1992), David, Saul und die Propheten: Das Verhältnis von Religion und Politik nach den prophetischen Überlieferungen vom frühesten Königtum in Israel, 2nd edn. (BWANT 122; Stuttgart: Kohlhammer).

-(1997), Die frühe Königszeit in Israel: 10. Jahrhundert v. Chr. (Biblische Enzyklopädie 3; Stuttgart: Kohlhammer).

-(2011), Samuel. Teilband 1. 1Sam 1-12 (BKAT 8/1; Neukirchen-Vluyn: Neukirchener).

-(2012-14), Samuel. Teilband 2. Lieferungen 1-7 (BKAT 8/2; Neukirchen-Vluyn: Neukirchener Verlag).

Dijkstra, Jan, Meindert Dijkstra and Karel J. H. Vriezen (2009), Tall Zar'a in Jordan: Report on the sondage at Tall Zar'a 2001-2002 (Gadara Region Project: Tall Zira'a) (BAR Int. Ser. 1980; Oxford: Archaeopress).

Dijkstra, Meindert (2009), 'A Chief of the Bowmen, Overseer of the Foreign Lands at Serabit el-Khadim (Sinai 300+297) and the "Dwelling of Sesu" (Tell el-Borg)', Ägypten und Levante 19: 121-25.

-(2011), 'Origins of Israel between History and Ideology', in Bob Becking and Lester L. Grabbe (eds), Between Evidence and Ideology. Essays on the History of Ancient Israel Read at the Joint Meeting of the Society for Old Testament Study and the Oud-Testamentisch Werkgezelschap Lincoln, July 2009 (OTS 59; Leiden: Brill), 41-82.

Dijkstra, Meindert and Karel J. H. Vriezen (2014), 'The Assyrian Province of Gilead and the "Myth of the Empty Land", in Eveline J. van der Steen et al. (eds), Exploring the Narrative. Jerusalem and Jordan in the Bronze and Iron Ages (Fs Margreet Steiner) (LHBOTS 583; London: Bloomsbury), 3-22.

Dobbs-Allsopp, Frederick William et al. (2005), Hebrew Inscriptions: Texts from the Biblical Period of the Monarchy with Concordance (New Haven: Yale University Press).

Dogniez, Cécile (2005), 'Aggée et ses suppléments (TM et LXX) ou le developpement litteraire d'un livre biblique', in Jan Joosten and Philippe le Moigne (eds), L'Apport de la Septante aux études sur l'Antiquité (Lectio Divina 203; Paris: Editions du Cerf), 197-218. 
Donner, Herbert (1984), Geschichte des Volkes Israel and seine Nachbarn in Grundzügen (ATD Ergänzungsreihe 4/1; Göttingen: Vandenhoeck \& Ruprecht).

Dorsey, David A. (1991), The Roads and Highways of Ancient Israel (The ASOR Library of Biblical and Near Eastern Archaeology; Baltimore: John Hopkins University).

Dothan, Moshe (ed.) (1971), Ashdod II-III: The Second and Third Seasons of Excavations 1963, 1965, Soundings in 1967 ('Atiqot, English Series 9/10, 2 vols; Jerusalem: The Israel Exploration Society).

Dozeman, Thomas B. (2009), Commentary on Exodus (Eerdmans Critical Commentary; Grand Rapids, MI: William B. Eerdmans).

Du Rand, Jan A. (1991), 'A Syntactical and Narratological Reading of John 10 in Coherence with Chapter 9', in Johannes Beutler and Robert T. Fortna (eds), The Shepherd Discourse of John 10 and its Context (SNTSMS 67; Cambridge: Cambridge University Press), 94-115, 161-3.

Duhm, Bernhard (1901), Das Buch Jeremia (KHCAT; Tübingen: Mohr).

Dussaud, René (1935), 'Deux stèles de Ras Shamra portant une dédicace au dieu Dagon', Syria 16: $177-80$.

Ebach, Jürgen (1995), 'Fremde in Moab - Fremde aus Moab', in Jürgen Ebach and Richard Faber (eds), Bibel und Literatur (München: Fink), 277-304.

Eberharter, Andreas (1911), Der Kanon des Alten Testaments zur Zeit des Ben Sira (ATAbh 3/3; Münster: Aschendorff).

Edel, Elmar (1978), 'Amasis und Nebukadrezar II', Göttinger Miszellen: Beiträge zur ägyptischen Diskussion 29: 13-20.

-(1980), Neue Deutungen keilschriftlicher Umschreibungen ägyptischer Wörter und Personennamen (DÖAW.PH, Sitzungsberichte 375; Wien: Österreichische Akademie der Wissenschaften).

Eggler, Jürg and Othmar Keel (2006), Corpus der Siegel-Amulette aus Jordanien vom Neolithikum bis zur Perserzeit (OBO Series Archeologica 25; Fribourg, Göttingen: Academic Press Fribourg, Vandenhoeck \& Ruprecht).

Ehrlich, Arnold B. (1912), Randglossen zur hebräischen Bibel: textkritisches, sprachliches und sachliches, 4: Jesaia, Jeremia (Leipzig: Hinrich).

Eissfeldt, Otto (1964), Einleitung in das Alte Testament unter Einschluss der Apokryphen und Pseudepigraphen sowie der apokryphen- und pseudepigraphenartigen QumranSchriften: Entstehungsgeschichte des Alten Testaments (Tübingen: Mohr).

-(1966), 'Etymologische und archäologische Erklärung alttestamentlicher Wörter', Oriens Antiquus 5: 165-76.

-(1969), 'Kultvereine in Ugarit', in C. F. A. Schaeffer (ed.), Ugaritica VI (MRS 17; Paris: Imprimerie Nationale and Librairie Orientaliste Paul Geuthner), 187-95.

Ellis, Teresa Ann (2013). Gender in the Book of Ben Sira: Divine Wisdom, Erotic Poetry, and the Garden of Eden (BZAW 453; Berlin).

Emerton, John A. (2006), 'The Kingdoms of Judah and Israel and Ancient Hebrew History Writing, in Steven E. Fassberg and Avi Hurvitz (eds), Biblical Hebrew in it Northwest Semitic Setting (Jerusalem: Hebrew University Magness Press), 33-49.

Engler, Steven and Michael Stausberg (eds) (2011), 'Crisis and Creativity: Opportunities and Threats in the Global Study of Religion/s', Religion 41/2: 127-43.

Erman, Adolf and Herman Grapow (1926-63), Wörterbuch der Aegyptischen Sprache (7 vols; Leipzig: Hinrichs).

Evans, James. A. (2008), Daily life in the Hellenistic Age: from Alexander to Cleopatra (Westport: Greenwood Press). 
Eykman, Karel (1976), Woord voor Woord. Kinderbijbel: Het Oude Testament (Wageningen: Zomer \& Keuning).

Fabry, Hainz-Josef (1998), 'מרזח marzēah', in G. Johannes Botterweck, Helmer Ringgren and Heinz-Josef Fabry (eds), Theological Dictionary of the Old Testament IX (Grand Rapids, MI and Cambridge: William B. Eerdmans), 10-15.

Fales, Mario F. (2001), L'impero assiro: Storia e amministrazione (IX-VII secolo a.C.) (Rome/Bari: Laterza).

Fantalkin, Alexander and Oren Tal (2012), 'The Canonization of the Pentateuch: When and Why?', Zeitschrift für die alttestamentliche Wissenschaft 124: 1-18 and 201-12.

Farber, Walter (1981), 'Zur älteren akkadischen Beschwörungsliteratur', ZA 71: 51-72.

-(1989), Schlaf, Kindchen, Schlaf! Mesopotamische Baby-Beschwörungen und Rituale (Winona Lake: Eisenbrauns, 1989).

Faust, Avraham (2008), 'Settlement and Demography in Seventh-Century Judah and the Extent and Intensity of Sennacherib's Campaign', PEQ 140: 168-94.

Feddersen, Jacob Frederik (1817), Leerzame verhalen uit de bijbelsche geschiedenissen, voor kinderen, 3rd edn (Amsterdam: Willem van Vliet).

Feldman, Louis H. (1998), Josephus's Interpretation of the Bible (Berkeley: University of California Press).

Fenton, Terry L. (1977), 'The Claremont “mrzh” Tablet: Its Text and Meaning', UF 9: 71-6.

Fink, Amir Sumaka'i (2007), 'Where was the Statue of Idrimi Actually Found? The Later Temples of Tell Atchana (Alalakh) Revisited', UF 39: 161-245.

Finkelberg, Margalit (2012), 'Canonising and Decanonising Homer: Reception of the Homeric Poems in Antiquity and Modernity', in Maren R. Niehoff (ed.), Homer and the Bible in the Eyes of Ancient Interpreters (Leiden: Brill).

Finkelstein, Israel (1988), The Archaeology of Israelite Settlement (Jerusalem: IES).

-(1996), 'Ethnicity and Origin of the Iron I Settlers in the Highlands of Canaan: Can the Real Israel Stand Up?', BA 59: 198-212.

-(1998), 'The Rise of Early Israel: Archaeology and Long-Term History', in Shmuel Ahituv and Eliezer D. Oren (eds), The Origin of Early Israel - Current Debate (Beer-Sheva 7; Beer-Sheva: Beer Shevah University).

Finkelstein, Israel and Avi Perevolotsky (1990), 'Processes of Sedentarization and Nomadization in the History of Sinai and the Negev', BASOR 279: 67-86.

Finkelstein, Israel and Neil Asher Silberman (2006), 'Temple and Dynasty: Hezekiah, the Remaking of Judah and the Rise of the Pan-Israelite Ideology', JSOT 30: 259-85.

Finkelstein, Israel, Ido Koch and Oded Lipschits (2011), 'The Biblical Gilead', UF 43: 131-59.

Fischer, Georg (2005), Jeremia 26-52 (HThK.AT; Freiburg: Herder).

Fischer, Irmtraud (2001), Rut: Übersetzt und ausgelegt (HThK.AT; Freiburg: Herder).

Fischer, Peter M. and Teresa Bürge (2013), 'Cultural Influences of the Sea Peoples in Transjordan. The Early Iron Age at Tell Abu Haraz', ZDPV 129: 132-70.

Fisher, Michael H. (1991), Indirect Rule in India: Residents and the Residency System 1764-1858 (Delhi: Oxford University Press).

Foucault, Michel (1984), 'Des espaces autres', reprinted in Dits et Écrits II 1976-1988 (Paris: Gallimard, 2001), 1571-81.

Fox, Michael V. (1989), Qohelet and His Contradictions (JSOTSup 71/BLS 18; Sheffield: Sheffield Academic Press).

—(2004), Ecclesiastes (The JPS Bible Commentary; Philadelphia: Jewish Publication Society).

Franke, John R. (2005), Joshua, Judges, Ruth, 1-2 Samuel (Ancient Christian Commentary on Scripture: Old Testament 4; Downers Grove: Intervarsity Press). 
Franken, Hendricus Jacobus (1989), 'Deir 'Alla (Tell)', in D. Homès-Fredericq and J. B. Hennessy (eds), The Archaeology of Jordan. II.1 Field Reports: Surveys and Sites A-K (Louvain: Peeters), 201-5.

Franken, Hendricus Jacobus and Jan Kalsbeek (1969), Excavations at Tell Deir Alla I (Leiden: Brill).

-(1992), Excavations at Tell Deir Alla: The Late Bronze Sanctuary (Louvain: Peeters).

Franklin, Norma (2003), 'The Tombs of the Kings of Israel. Two Recently Identified 9th-Century Tombs from Omride Samaria, ZDPV 119: 1-11.

-(2007a), 'Lost Tombs of the Israelite Kings', BAR 33/4: 26-35.

-(2007b), 'Response to David Ussishkin', BASOR 348: 71-3.

Fretheim, Terence (2002), Jeremiah (Smyth \& Helwys Bible Commentary; Macon, GA: Smyth \& Helwys).

Frevel, Christian (1992), Das Buch Rut (Neue Stuttgarter Kommentar Altes Testament; Stuttgart: Katholisches Bibelwerk).

Fried, Lisbeth S. (2001), "You Shall Appoint Judges": Ezra's Mission and the Rescript of Artaxerxes', in James W. Watts (ed.), Persia and Torah: The Theory of Imperial Authorization of the Pentateuch (SBLSS 17; Atlanta: Society of Biblical Literature), 63-89.

Friedman, Richard Elliott (1979-80), 'The mrzh Tablet from Ugarit', Maarav 2: 187-206.

Friedrich, Johannes (1930), 'Die hethitischen Bruchstücke des Gilgamesh-Epos', ZA 39: $1-82$.

Fritz, Volkmar (1971), 'Erwägungen zu dem spätbronzezeitlichen Quadratbau bei Amman', ZDPV 87: 140-52.

-(1987), 'Conquest and Settlement. The Early Iron Age in Palestine', BA 50: 84-99.

-(1995), The City in Ancient Israel (Sheffield: Sheffield Academic Press).

Fritz, Volkmar and Aharon Kempinski (1983), Ergebnisse der Ausgrabungen auf der Hirbet el-Msas (Tel Masos) 1972-1975 (ADPV; Wiesbaden: Harrasowitz).

Frolov, Sergei and Allen Wright (2011), 'Homeric and Ancient Near Eastern: Intertextuality in 1 Samuel 17', JBL 130: 451-71.

Fuchs, Avraham (1998), Die Annalen des Jahres 711 v. Chr. nach Prismenfragmenten aus Ninive und Assur (SAAS 8; Helsinki: University of Helsinki).

Gadot, Yuval (2010), 'The Late Bronze Egyptian Estate at Apheq', Tel Aviv 37: 48-66.

Gallagher, William R. (1999), Sennacherib's Campaign to Judah: New Studies (SHCANE 18; Leiden: Brill).

Galling, Kurt (1959), 'Erwägungen zum Stelenheiligtum von Hazor', ZDPV 75: 1-13.

Gasser, Johann Konrad (1904), Die Bedeutung der Sprüche Jesu ben Sira für die Datierung des althebräischen Spruchbuches (BFCT 8/2-3; Gütersloh: Bertelsmann).

Geiger, Michaela (2010), Gottesräume: Die literarische und theologische Konzeption von Raum im Deuteronomium (BWANT 183; Stuttgart: Kohlhammer).

Gerleman, Gillis (1965), Ruth. Das Hohelied (BKAT 18; Neukirchen: Neukirchener Verlag).

Gertz, Jan Christian (2000), Tradition und Redaktion in der Exoduserzählung: Untersuchungen zur Endredaktion des Pentateuch (FRLANT 186; Göttingen: Vandenhoeck \& Ruprecht).

Geva, Hillel (2003), 'Western Jerusalem at the End of the First Temple Period in Light of the Excavations in the Jewish Quarter', in Vaughn and Killebrew 2003: 183-208.

Gibson, Shimon (2001), 'Agricultural Terraces and Settlement Expansion in the Highlands of Early Iron Age Palestine: Is There Any Correlation between the Two?', in Amihai Mazar (ed.), Studies in Archaeology of the Iron Age in Israel and Jordan (JSOTSup 331; Sheffield: Sheffield Academic Press), 113-46. 
-(2012), 'A New Dating Scheme for the Water System and Fortifications at Gibeon/el-Jib', paper presented in the Program Unit 'Archaeology' at the EABS-SBL conference in Amsterdam, July 2012.

Giesebrecht, Friedrich (1907), Das Buch Jeremia übersetzt und erklärt, 2nd edn (HKAT; Göttingen: Vandenhoeck \& Ruprecht) (second printing).

Gilbert-Peretz, Diana (1996), 'Ceramic figurines', in Donald T. Ariel and Alon de Groot (eds), Excavations at the City of David 1978-1985. Volume IV: Various Reports (Qedem 35; Jerusalem: Hebrew University), 29-134 (including appendices contributed by others).

Gilmour, Garth and Kenneth A. Kitchen (2012), 'Pharaoh Sety II and Egyptian Political Relations with Canaan at the end of the Late Bronze Age', IEJ 62: 1-21.

Ginsberg, H. L. (1969), 'Job the Patient and Job the Impatient', in Congress Volume Rome 1968 (VTSup 17; Leiden: Brill), 88-111.

Glassner, Jean-Jacques (2004), Mesopotamian Chronicles (Published in French 1993, B. R. Foster (ed.). Writings from the Ancient World 19; Atlanta, GA; Society of Biblical Literature).

Glenny, W. Edward (2009), Finding Meaning in the Text. Translation Technique and Theology in the Septuagint of Amos (VTSup 126; Leiden: Brill).

Glover, Neil (2009), 'Your People, My People: An Exploration of Ethnicity in Ruth', JSOT 33: 293-313.

Glueck, Nelson (1939), Explorations in Eastern Palestine III (Annual of the American Schools of Oriental Research XVIII-XIX, 1937-9; New Haven: ASOR).

-(1951), Explorations in Eastern Palestine IV (Annual of the American Schools of Oriental Research XXV-XXVIII, 1951; New Haven: ASOR).

Gnuse, Robert (2008), 'Abducted Wives: A Hellenistic Narrative in Judges 21?', SJOT 22: 228-40.

Gollwitzer, Helmut (1972), Krummes Holz - aufrechter Gang: Zur Frage nach dem Sinn des Lebens, 5th edn (München: Chr. Kaiser).

Gordis, Robert (1951), Koheleth - The Man and His World (Texts and Studies of the Jewish Theological Seminary of America 19; New York: Jewish Theological Seminary).

Gordon, Cyrus H. (1955), 'Homer and Bible: The Origin and Character of East Mediterranean Literature', HUCA 26: 43-108.

Gordon, Lyndall (1998), T.S. Eliot: An Imperfect Life (New York and London: W. W. Norton).

Görg, Manfred (1989), Beiträge zur Zeitgeschichte der Anfänge Israels (Ägypten und Altes Testament 2; Wiesbaden: Harrasowitz).

Gow, Murray D. (1992), The Book of Ruth: Its Structure, Theme and Purpose (Leicester: Apollos).

Grabbe, Lester L. (1992), Judaism from Cyrus to Hadrian: Vol. I: Persian and Greek Periods; Vol. II: Roman Period (Minneapolis: Fortress Press).

-(1998), Ezra and Nehemiah (Readings; London: Routledge).

-(2000), Judaic Religion in the Second Temple Period: Belief and Practice from the Exile to Yavneh (London and New York: Routledge).

-(2002), 'The Hellenistic City of Jerusalem', in John R. Bartlett (ed.), Jews in the Hellenistic and Roman Cities (London: Routledge), 6-21.

-(2004), A History of the Jews and Judaism in the Second Temple Period 1: Yehud: A History of the Persian Province of Judah (Library of Second Temple Studies 47; London and New York: T \& T Clark International).

-(2005), A review of Moorey's Schweich Lecture, published as Moorey, Idols of the People (2003) in JSOT 29: 28. 
-(2006), 'The "Persian Documents" in the Book of Ezra: Are They Authentic?', in Oded Lipschits and Manfred Oeming (eds), Judah and the Judeans in the Persian Period (Winona Lake, IN: Eisenbrauns), 531-70.

-(2013) 'Elephantine and the Torah', in Alejandro F. Botta (ed.), In the Shadow of Bezalel: Aramaic, Biblical, and Ancient Near Eastern Studies in Honor of Bezalel Porten (Culture and History of the Ancient Near East 60; Leiden and Boston: Brill), 125-35.

-(2014), 'Religious and Cultural Boundaries from the Neo-Babylonian to the Early Greek Period: A Context for Iconographic Interpretation', in Christian Frevel, Katharina Pyschny and Izak Cornelius (eds), A 'Religious Revolution' in Yehûd? The Material Culture of the Persian Period as a Test Case (OBO 267; Fribourg: Academic Press; Göttingen: Vandenhoeck \& Ruprecht), 23-42.

Grabbe, Lester L. (ed.) (2001), Did Moses Speak Attic? Jewish Historiography and Scripture in the Hellenistic Period (Sheffield: Sheffield Academic Press).

Grandia, Bram (2005), 'Een verhaal over een migrerende vrouw die weduwe en vreemdelinge wordt', in Met Ruth op weg: Overwegingen over migratie, terugkeer en integratie (OIKOS; Den Haag: Justitia \& Pax), 9-12.

Gray, G. Buchanan (1912), A Critical and Exegetical Commentary on the Book of Isaiah I-XXVII (ICC; Edinburgh: T \& T Clark).

Grayson, A. Kirk (2000), Assyrian and Babylonian Chronicles (First published 1975 in the series Texts from Cuneiform Sources 5; Reprinted Winona Lake, IN: Eisenbrauns).

Grayson, A. Kirk and Jamie Novotny (2012), The Royal Inscriptions of Sennacherib, King of Assyria (704-681 BC), Part 1 (RINAP 3/1; Winona Lake: Eisenbrauns).

-(2014), The Royal Inscriptions of Sennacherib, King of Assyria (704-681 BC), Part 2 (RINAP 3/2; Winona Lake: Eisenbrauns).

Gräz, Sebastian (2004), Das Edikt des Artaxerxes: Eine Untersuchung zum religionspolitischen und historischen Umfeld von Esra 7,12-26 (BZAW 337; Berlin: De Gruyter).

Green, John D. M. (2009), 'Forces of Transformation in Death: The Cemetery at Tell es-Sa'idiyeh, Jordan', in Christoph Bachhuber and R. Gareth Roberts (eds), Forces of Transformation: The End of the Bronze Age in the Mediterranean. Proceedings of an International Symposium Held at St. John's College, University of Oxford, 25-6 March 2006 (British Association for Near Eastern Archaeology Publication SeriesVol.1; Oxford: Oxbow Books), 89-91.

-(2011), 'The Jordan Valley: The Cemetery at Tell es-Sa'idiyeh, Jordan', in Mario Martin (ed.), Egyptian-Type Pottery in the Late Bronze Age Southern Levant, Part III. The Egyptian Assemblages at the Various Sites (Wien: Verlag des Österreichischen Akademie der Wissenschaften), 162-74.

Greenfield, Jonas C. (1974), 'The Marzeah as a Social Institution', Acta Antiqua Academiae Scientiarum Hungaricae 22: 451-5.

Greer, Jonathan S. (2007), 'A Marzeah and a Mizraq: A Prophet's Mêlée with Religious Diversity in Amos 6.4-7', JSOT 32: 243-62.

Grimal, Nicolas (1995), A History of Ancient Egypt (trans. Ian Shaw; published in French 1988; Oxford: Blackwell).

Gröndahl, Frauke (1967), Die Personennamen der Texte aus Ugarit (Studia Pohl 1; Rome: Päpstliches Bibelinstitut).

Groot, Alon de and Hannah Bernick-Greenberg (2012), Excavations at the City of David, Volume 7A: Area E: Stratigraphy and Architecture (text) (Qedem 53; Jerusalem: Hebrew University).

Groß, Walter (2009), Richter (HThK.AT; Freiburg im Breisgau: Herder). 
Guillaume, Philippe (2008), 'Jerusalem 722-705 BCE: No Flood of Israelite Refugees', SJOT 22: 195- 211.

Gunkel, Hermann (1924), 'Der Micha-Schluß: Zur Einführung in die literaturgeschichtliche Arbeit am Alten Testament', Zeitschrift für Semitistik 2: $145-78$.

Gunneweg, Antonius H. J. (1985), Esra (KAT 19.1; Gütersloh: Mohn).

Haas, Volkert (1994), Geschichte der hethitischen Religion (HdO I/15; Leiden: Brill).

Hagstrom, David G. (1988), The Coherence of the Book of Micah: A Literary Analysis (SBLDS 89; Atlanta: Scholars Press).

Hallo, William W. (ed.) (2000), The Context of Scripture, Vol. 2: Monumental Inscriptions from the Biblical World (Leiden: Brill).

Hartenstein, Friedhelm (2004), 'JHWH und der "Schreckensglanz" Assurs (Jesaja 8,6-8): Traditions- und religionsgeschichtliche Beobachtungen zur "Denkschrift" Jesaja 6- 8, in Friedhelm Hartenstein, Jutta Krispenz and Aaron Schart (eds), Schriftprophetie: Festschrift für Jörg Jeremias zum 65. Geburtstag (Neukirchen-Vluyn: Neukirchener Verlag, 2004), 83-102, repr. in Friedhelm Hartenstein, Das Archiv des verborgenen Gottes: Studien zur Unheilsprophetie Jesajas und zur Zionstheologie der Psalmen in assyrischer Zeit (BThS 74; Neukirchen-Vluyn: Neukirchener Verlag, 2011), 1-30.

Hausmann, Jutta (2005), Ruth: Miteinander auf dem Weg (Biblische Gestalten 11; Leipzig: Evangelische Verlagsanstalt).

Hemel, Ernst van den (2014), '(Pro)claiming Tradition: The "Judeo-Christian" Roots of Dutch Society and the Rise of Conservative Nationalism', in Rosi Braidotti et al. (eds), Transformations of Religion and the Public Sphere: Postsecular Publics (London: Palgrave MacMillan), 53-76.

Hempel, J. (1960), 'Die Lichtsymbolik im Alten Testament', Studium Generale 13: 352-68.

Hermisson, Hans-Jürgen (1998), Studien zu Prophetie und Weisheit: Gesammelte Aufsätze (FAT 23; Tübingen: Mohr Siebeck).

Herr, Larry G. (1983), 'The Amman Airport Structure and the Geopolitics of Ancient Transjordan,' BA 46: 223-30.

-(2009), 'Jordan in the Iron Age Period', Studies in the History and Archaeology of Jordan 10: 549-61.

Herr, Larry G. and Douglas R. Clark (2009), 'From the Stone Age to the Middle Ages in Jordan. Digging up Tall al-'Umayri', Near Eastern Archaeology 72: 68-97.

Herr, Larry G. and Muhammad Najjar (2001), 'The Iron Age', in MacDonald et al., $323-45$.

Herring, Stephen L. (2013), Divine Substitution: Humanity as the Manifestation of Deity in the Hebrew Bible and the Ancient Near East (FRLANT 247; Göttingen: Vandenhoeck \& Ruprecht).

Hertzberg, Hans Wilhelm (1965), Die Samuelbücher (ATD 10; Göttingen: Vandenhoeck \& Ruprecht).

Herzog, Zeev (1994), 'The Valley of Beer-Sheva: From Nomadism to Monarchy', in Israel Finkelstein and Nadav Na'aman, From Nomadism to Monarchy: Archaeological and Historical Aspects of Early Israel (Jerusalem: Yad Izhak Ben-Zwi), 122-49.

Hibbard, J. Todd (2006), Intertextuality in Isaiah 24-27. The Reuse and Evocation of Earlier Texts and Traditions (FAT II/16; Tübingen: Mohr Siebeck).

Hicks-Keeton, Jill (2013), 'Already/Not Yet: Eschatological Tension in the Book of Tobit', $J B L$ 132: 97-117.

Hoch, James E. (1994), Semitic Words in Egyptian Texts of the New Kingdom and Third Intermediate Period (Princeton, NJ: Princeton University Press). 
Hoffmeier, James K. (2003), 'Egypt's Role in the Events of 701 B.C. in Jerusalem', in Vaughn and Killebrew, 219-34.

Holy Bible, The (1952), Revised Standard Version Containing the Old and New Testaments (Toronto: Thomas Nelson \& Sons).

Homès-Fredericq, Denyse (2000), 'Excavating the First Pillar House at Lehun (Jordan)', in Lawrence A. Stager, Joseph A. Greene and Michael D. Coogan (eds), The Archaeology of Jordan and Beyond: Essays in Honor of James A. Sauer (Winona Lake: Eisenbrauns), $180-95$.

Honig, Bonnie (1999), 'Ruth, the Model Emigrée: Mourning and the Symbolic Politics of Immigration', in Athalya Brenner (ed.), A Feminist Companion to Ruth and Esther (Sheffield: Sheffield Academic Press), 50-74.

Hornung, E. (1965), 'Licht und Finsternis in der Vorstellungswelt Altägyptens', Studium Generale 18: 73-83.

Houston, Walter (2004), 'Was There a Social Crisis in the Eighth Century?', in John Day (ed.), In Search of Pre-Exilic Israel: Proceedings of the Oxford Old Testament Seminar (JSOTSup 406; London: T \& T Clark), 130-49.

Houten, Ulbe van s.a. (1959), De heilige geschiedenis: Vol. 1: Het Oude Testament (Oorspronkelijke titel: De Hillige Histoarje. Uit het Fries vertaald door Arjen Miedema; Franeker: Wever).

Houtman, Cornelis (1998a), Een wellustige en valse vrouw? Over een intrigerende 'affaire' in Schrift en uitleg (Kampen: Kok).

—(1998b), 'Wer kann Sünden vergeben außer Gott allein? Über menschliche Vergebung im Alten Testament', Biblische Notizen 95: 33-44.

- (2003), 'Theodicy in the Pentateuch', in Antti Laato and Johannes C. de Moor (eds), Theodicy in the World of the Bible (Leiden: Brill), 151-82.

-(2006), De Schrift wordt geschreven: Op zoek naar een christelijke hermeneutiek van het Oude Testament (Zoetermeer: Meinema).

-(2010), Bijbelse geschiedenis herverteld: Woord en beeld - Vraag en antwoord (Heerenveen: Groen).

-(2011), 'Drie negentiende-eeuwse kinderbijbels "uitgelicht", Met Andere Woorden 11/1: $14-23$.

- (2013), 'Naar protestants voorbeeld: Leerstof over de bijbelse geschiedenis uit het tijdperk van de joodse emancipatie', Kerk en Theologie 64: 162-83.

Hubbard Jr., Robert L. (1988), The Book of Ruth (NICOT; Grand Rapids: Eerdmans).

Hulster, Izaak J. de (2012), 'Figurines from Persian Period Jerusalem?', ZAW 124: 73-88.

-(forthcoming), Figurines in Achaemenid Period Yehud: Jerusalem's History of Religion and the Issue of Monotheism (working title).

Hunt, Steven A., D. Francois Tolmie and Ruben Zimmermann (eds) (2013), Character Studies in the Fourth Gospel: Narrative Approaches to Seventy Figures in John (WUNT 314; Tübingen: Mohr Siebeck).

Ibrahim, Moawiyah M. (1972), 'Archaeological Excavations at Sahab, 1972', ADAJ 17: 23-36, 117-22.

-(1987), 'Sahab and its Foreign Relations', Studies in the History and Archaeology of Jordan 3: 73-81.

Inowlocki, Sabrina (2011), 'Eusebius' Construction of a Christian Culture in an Apologetic Context: Reading the Praeparatio evangelica as a Library', in Sabrina Inowlocki and Claudio Zamagni (eds), Reconsidering Eusebius: Collected Papers on Literary, Historical, and Theological Issues (Supplements to Vigiliae Christianae 107; Leiden: Brill). 
Issar, Arie S. and Mattanyah Zohar (2004), Climate Change: Environment and Civilization in the Middle East (Berlin: Springer).

Jacobs, Mignon R. (2001), The Conceptual Coherence of the Book of Micah (JSOTSup 322; Sheffield: Sheffield Academic Press).

Jacobsen, Thorkild (1976), The Treasures of Darkness: History of Mesopotamian Religion (New Haven: Yale University).

-(1987), 'The Graven Image', in Patrick D. Miller Jr. et al. (eds), Ancient Israelite Religion (Philadelphia: Fortress), 15-32.

Jacquet, Antoine (2002), 'LUGAL-MEŠ et MALIKUM. Nouvel examen du kispum à Mari', in Dominique Charpin and Jean-Marie Durand (eds), Florilegium Marianum 6: Recueil détudes à la mémoire d'André Parrot (Mémoires de NABU 7; Paris: SEPOA), $51-68$.

James, Thomas G. H. (2000), 'Egypt: The Twenty-Fifth and Twenty-Sixth Dynasties', in John Boardman et al. (eds), The Assyrian and Babylonian Empires and other States of the Near East, from the Eight to the Sixth Centuries B.C., 2nd edn (The Cambridge Ancient History 3/2; Cambridge: Cambridge University Press), 677-747.

Janowski, Bernd (2004), 'Die lebendige Statue Gottes: Zur Anthropologie der priesterlichen Urgeschichte', in Markus Witte (ed.), Gott und Mensch im Dialog: Festschrift für Otto Kaiser zum 80. Geburtstag (BZAW 345; Berlin and New York: De Gruyter), 183-214.

Janssen, Kolet (2004), Het grote avontuur van God en mens: Kinderbijbel met meer dan 150 verhalen (Leuven: Davidsfonds; Kampen: Kok).

Jepsen, Alfred (1937), 'Das Buch Ruth', Theologische Studien und Kritiken 108: 416-28. Jeremias, Jörg (1977), Theophanie: Die Geschichte einer alttestamentlichen Gattung, 2nd edn (WMANT 10; Neukirchen-Vluyn: Neukirchener Verlag).

-(2007), Die Propheten Joel, Obadja, Jona, Micha (ATD 24/3; Göttingen: Vandenhoeck \& Ruprecht).

Ji, Chang-Ho C. (1995), 'Iron Age I in Central and Northern Transjordan: An Interim Summary of Archaeological Data', PEQ 127: 122-40.

Joannès, Francis (2004), The Age of Empires: Mesopotamia in the First Millennium BC (trans. Antonia Nevill from French; Edinburgh: Edinburgh University Press).

Joannès, Francis and André Lemaire (1996), 'Trois tablettes cunéiformes à onomastique ouestsémitique (collection Sh. Moussaieff)', Transeuphratène 17: 17-34.

Jones, Douglas (1992), Jeremiah (NCB; Grand Rapids, MI: Eerdmans).

Jong, Matthijs J. de (2007), Isaiah among the Ancient Near Eastern Prophets: A Comparative Study of the Earliest Stages of the Isaiah Tradition and the Neo-Assyrian Prophecies (VTSup 117; Leiden: Brill).

-(2012), 'The Fallacy of "True and False" in Prophecy Illustrated by Jer 28:8-9', JHS 12: Article 10.

Joosten, Jan (2014), 'Hebrew Thought and Greek Thought in the Septuagint Fifty Years after Barr's Semantics', in Richard A. Taylor and Craig E. Morrison (eds), Reflections on Lexicography: Explorations in Ancient Syriac, Hebrew, and Greek Sources (Perspectives on Linguistics and Ancient Languages 4; Piscataway: Gorgias Press), 149-157.

Joüon, Paul and Takamitsu Muraoka (1991), A Grammar of Biblical Hebrew I-II (SubBi 14/I-II; Roma: Pontificio Istituto Biblico).

Kafafi, Zeidan A. (1985), 'Egyptian Topographical Lists of the Late Bronze Age in Jordan (East Bank), BN 29: 17-21.

Kafafi, Zeidan A. and Gerrit van der Kooij (2013), 'TDA during the Transition from LB to IA', ZDPV 129: 121-31. 
Kalimi, Isaac (2014), 'Sennacherib's Campaign to Judah: The Chronicler's View Compared with His "Biblical" Sources', in I. Kalimi and S. Richardson (eds), Sennacherib at the Gates of Jerusalem: Story, History and Historiography (Leiden: Brill), 11-50.

Kaniewski David, Etienne Paulissen, Elise Van Campo, Harvey Weiss, Thierry Otto, Joachim Bretschneider and Karel Van Lerberghe (2010), 'Late Second-Early First Millennium BC Abrupt Climate Changes in Coastal Syria and Their Possible Significance for the History of the Eastern Mediterranean', Quaternary Research 74: $207-15$.

Kaptijn, Eva (2014), 'The Late Bronze and Iron Age Cultural Landscape of the Eastern Jordan Valley: The Start of a Long Tradition', in Eveline J. van der Steen et al. (eds), Exploring the Narrative. Jerusalem and Jordan in the Bronze and Iron Ages (Fs Margreet Steiner) (Library of Hebrew Bible/Old Testament Studies 583; London: Bloomsbury), 23-45.

Karff, Rabbi Samuel E. (1989), Funeral Service for Rabbi Daniel Jeremy Silver, December 24, 1989 (Cleveland, OH: The Temple).

Kaser, Karl (2011), Balkan und Naher Osten: Einführung in eine gemeinsame Geschichte (Zur Kunde Südosteuropas 2/40; Wien: Böhlau).

Keel, Othmar (1977), Die Welt der altorientalischen Bildsymbolik und das Alte Testament, 2nd edn (Zürich: Benziger).

—(1986), Das Hohelied (ZBKAT 18; Zürich: Theologischer Verlag).

Keel, Othmar and Christoph Uehlinger (1998), Gods, Goddesses, and Images of God in Ancient Israel (trans. Thomas H. Trapp; Minneapolis: Fortress Press).

-(2012), Göttinnen, Götter und Gottessymbole: Neue Erkenntnisse zur Religionsgeschichte Kanaans und Israels aufgrund bislang unerschlossener ikonographischer Quellen, 7th edn (Quaestiones disputatae 134; Freiburg im Breisgau: Herder).

Kennedy, David (2007), Gerasa and the Decapolis: A Virtual Island in Northwest Jordan, (London: Duckwell).

Kessler, John (2002), The Book of Hagga: Prophecy and Society in Early Persian Yehud (VTSup 91; Leiden: Brill)

Kessler, Rainer (1999), Micha übersetzt und ausgelegt (HThK.AT; Freiburg: Herder). Keulers, Jan Jozef Dominicus (1938), Bijbelsche geschiedenis, 2nd edn (Roermond \& Maaseik: Romen).

Killebrew, Ann E. (2005), Biblical Peoples and Ethnicity. An Archaeological Study of Egyptians, Canaanites, Philistine and Early Israel 1300-1100 BCE (Atlanta: SBL).

-(2006), 'The Emergence of Ancient Israel: The Social Boundaries of a "Mixed Multitude"', in Pierre de Miroschedji and Aren M. Maeir (eds), I Will Speak the Riddles of Ancient Times (Abiah chidoth minei-kedem - Ps 78:2b): Archaeological and Historical Studies in Honor of Amihai Mazar on the Occasion of his Sixtieth Birthday, vol. 2/4 (Winona Lake: Eisenbrauns).

Kipfer, Sara (2013), Der bedrohte David: Eine exegetische und rezeptionsgeschichtliche Studie zu 1Sam 16-1Kön 2 (Diss. theol. Bern).

Kitchen, Kenneth A. (1964), 'Some New Light on the Asiatic Wars of Ramesses II', JEA 50: 47-70.

-(1969), Ramesside Inscriptions Volume 2 (Oxford: Blackwell).

-(1992), 'The Egyptian Evidence on Ancient Jordan', in P. Bienkowski (ed.), Early Edom and Moab: The Beginning of the Iron Age in Southern Jordan (SAM 1; Sheffield: J. R. Collins Publications), 21-35.

-(1996), The Third Intermediate Period in Egypt (1100-650 B.C.), 2nd edn ( Warminster: Aris \& Phillips). 
Klengel, Horst (1981), 'Historischer Kommentar zur Inschrift des Idrimi von Alalah', UF 13: 269-78.

Kletter, Raz (1996), The Judean Pillar-figurines and the Archaeology of Asherah (BAR Int. Series 636; Oxford: Tempus Reparatum).

-(1998), Economic Keystones: The Weight System of the Kingdom of Judah (JSOTSup 276; Sheffield: Sheffield Academic Press).

Kloner, Amos and Esther Eshel (1999), 'A Seventh Century B.C.E. List of Names from Maresha' (in Hebrew), Eretz Israel 26: 147-50.

Knauf, Ernst Axel (1984), 'Abel Keramim', ZDPV 100: 119-21.

Koch, Klaus (1980), 'חטא', in G. Johannes Botterweck and Helmer Ringgren (eds), Theological Dictionary of the Old Testament, vol. 4 (Grand Rapids: Eerdmans), 309-19.

Kochavi, Moshe (1998), 'The Eleventh Century BCE Tripartite Pillar Building at Tel Hadar', in Seymour Gitin, Amihai Mazar and Ephraim Stern (eds), Mediterranean Peoples in Transition: Thirteenth to Early Tenth Century BCE (Jerusalem: IES), 468-78.

Kolakowski, Leszek (1965), Der Himmelsschlüssel: Erbauliche Geschichten (Bibliothek Suhrkamp 207; Frankfurt: Suhrkamp).

Kooij, Arie van der (1986), 'Das assyrische Heer vor den Mauern Jerusalems im Jahr 701 v. Chr.', ZDPV 102: 93-109.

-(1998), The Oracle of Tyre. The Septuagint of Isaiah 23 as Version and Vision (VTSup 71; Leiden: Brill).

-(2003), 'The Septuagint of Zechariah as Witness to an Early Interpretation', in Christopher Tuckett (ed.), The Book of Zechariah and its Influence (Aldershot: Ashgate), 53-64.

-(2010), 'Authoritative Scriptures and Scribal Culture', in Mladen Popović (ed.), Authoritative Scriptures in Ancient Judaism (JSJSup 141; Leiden: Brill), 55-71.

-(2013), 'The Septuagint and Scribal Culture', in Melvin K. H. Peters (ed.), XIV Congress of the IOSCS Helsinki, 2010 (SCS 59; Atlanta: SBL), 33-9.

Korpel, Marjo C. A. (1996), 'Exegesis in the Work of Ilimilku of Ugarit', in Johannes C. de Moor (ed.), Intertextuality in Ugarit and Israel (OTS 40; Leiden: Brill), 86-111.

-(2001), The Structure of the Book of Ruth (Pericope 2; Assen: Van Gorcum).

-(2005), 'Second Isaiah and the Greek Islands', in Michael Parsons (ed.), Text and Task: Scripture and Mission (Fs. John Olley; Milton Keynes: Paternoster Press), 79-90.

-(2009), 'Kryptogramme in Ezechiel 19 und im 'Izbet-Ṣarța-Ostrakon', ZAW 121: 70-86.

-(2011), 'The Messianic King: Isaiah 10:33-11:10', in Göran Eidevall and Blazenka Scheuer (eds), Enigmas and Images (Fs T. N. D. Mettinger) (CB.OT 548; Winona Lake: Eisenbrauns), 147-59.

Korpel, Marjo C. A. and Johannes C. de Moor (1998), The Structure of Classical Hebrew Poetry: Isaiah 40-55 (Leiden: Brill).

Korpel, Marjo C. A. and Josef M. Oesch (eds) (2002), Studies in Scriptural Unit Division (Pericope 3; Assen: Van Gorcum).

-(2011), The Silent God (Leiden: Brill).

Kraus, Hans-Joachim (1964), Prophetie in der Krisis: Studien zu Texten aus dem Buch Jeremia (Biblische Studien 43; Neukirchen-Vluyn: Neukirchener Verlag).

Krüger, Thomas (2004), Qoheleth, A Commentary (Hermeneia; Minneapolis: Fortress Press).

Küchler, Max (2007), Ein Handbuch und Studienreiseführer zur Heiligen Stadt (OLB IV/2; Göttingen: Vandenhoeck \& Ruprecht).

Kuehn, Thomas (2011), Empire, Islam, and Politics of Difference: Ottoman Rule in Yemen, 
1849-1919 (The Ottoman Empire and its Heritage: Politics, Society and Economy 48; Leiden: Brill).

Kuenen, Abraham (1887), Historisch-kritisch onderzoek naar het ontstaan en de verzameling van de boeken des Ouden Verbonds, deel 1: De Thora en de historische boeken des Ouden Verbonds (Amsterdam: S.L. van Looy).

-(1889), Historisch-critisch onderzoek naar het ontstaan en de verzameling van de boeken des Ouden Verbonds (deel 2; Leiden: P. Engels en Zoon).

Kuijt, Evert (1977), Kinderbijbel: Het Oude Testament ('s-Gravenhage: Boekencentrum).

Kunz-Lübcke, Andreas (2007), 'Interkulturell lesen! Die Geschichte von Jiftach und seiner Tochter in Jdc 11,30-40 in textsemantischer Perspektive', in Ludwig Morenz and Stefan Schorch (eds), Was ist ein Text? Alttestamentliche, Ägyptologische und altorientalische Perspektiven (Berlin: De Gruyter), 258-83.

Labahn, Michael (2003), 'Der Weg eines Namenlosen - vom Hilflosen zum Vorbild (Joh 9): Ansätze zu einer narrativen Ethik der sozialen Verantwortung im vierten Evangelium', in Roland Gebauer and Martin Meiser (eds), Die bleibende Gegenwart des Evangeliums (Fs O. Merk; Marburger theologische Studien 76; Marburg: Elwert), 63-80.

-(2009), "Blinded by the Light": Blindheit, Sehen und Licht in Joh 9. Ein Spiel von Variation und Wiederholung durch Erzählung und Metapher', in Gilbert Van Belle, Michael Labahn and Petrus Maritz (eds), Repetitions and Variations in the Fourth Gospel: Style, Text, Interpretation (BETL 223; Leuven: Peeters), 453-509.

Labuschagne, Casper J. (2013), 'Review of Philippe Wajdenbaum, Argonauts of the Desert: Structural Analysis of the Hebrew Bible, Review of Biblical Literature. http:// www.bookreviews.org

LaCocque, André (1990), The Feminine Unconventional: Four Subversive Figures in Israel's Tradition (Minneapolis: Fortress Press).

Lalkin, Nir (2004), 'A Ramesses IV Scarab from Lachish', Tel Aviv 31: 17-21.

Lambert, Wilfred G. (1971), 'Götterlisten', Reallexikon der Assyriologie 3: 473-9.

Lamprichs, Roland (1995), Die Westexpansion des neuassyrischen Reiches: Eine Strukturanalyse (AOAT 239; Neukirchen-Vluyn: Neukirchener Verlag).

-(2007), Tell Johfiyeh: Ein archäologischer Fundplatz und seine Umgebung in Nordjordanien, (Münster: Ugarit Verlag).

Lanfranchi, Giovanni B. (2009), 'A Happy Son of the King of Assyria: Warikas and the Çineköy Bilingual (Cilicia)', in Mikko Luuko et al. (eds), Of God(s), Trees, Kings, and Scholars (Fs Simo Parpola; Studia Orientalia 106; Helsinki: Finnish Oriental Society), $127-50$.

Langer, B. (1989), Gott als "Licht" in Israel und Mesopotamien: Eine Studie zu Jes 60,1-3,19f. (ÖBS 7; Klosterneuburg: Österreichisches Katholisches Bibelwerk).

Lauha, Aarre (1978), Kohelet (BKAT 19; Neukirchen-Vluyn: Neukirchener Verlag).

Lefebvre, Henri (1974, 1991), La production de l'espace (Paris: Anthropos); ET by D. Nicholson-Smith, The Production of Space (Oxford: Blackwell).

Leggett, Donald A. (1974), The Levirate and Goel Institutions in the Old Testament: With Special Attention to the Book of Ruth (Cherry Hill: Mack Publishing Company).

Lemaire, André (1997), 'Oracles, politique et literature dans les royaumes Araméens et Transjordaniens (IX ${ }^{\mathrm{e}}$-VIII ${ }^{\mathrm{e}}$ s. av. n.è.)', in Jean Georges Heintz (ed.), Oracles et prophéties dans lantiquité. Acts du Colloque de Strasbourg 15-17 juin 1995 (Travaux du Centre de recherche sur le Proche-Orient et la Grece antiques; Université des Sciences Humaines de Strasbourg 15; Paris: De Boccard), 171-93.

Lemche, Niels Peter (1993), 'The Old Testament - A Hellenistic Book?', SJOT 7: 163-93. -(2000), 'Good and Bad in History: The Greek Connection', in Steven L. McKenzie et 
al. (eds), Rethinking the Foundations: Historiography in the Ancient World and in the Bible: Essays in Honour of John Van Seters (BZAW 294; Berlin: De Gruyter), 127-40.

Lemos, Tracy M. (2012), “They Have Become Women”, Judean Diaspora and Postcolonial Theories of Gender and Migration', in Saul M. Olyan (ed.), Social Theory and the Study of Israelite Religion. Essays in Retrospect and Prospect (SBL Resources for Biblical Study 71; Atlanta: SBL), 81-109.

Lévi, Israel (1901), L’Ecclésiastique ou la Sagesse de Jésus, fils de Sira (BEHE.R 10/2; Paris: Leroux).

Levin, Yigal (2002), 'The Search for Moresheth-Gath: A New Proposal', PEQ 134: 28-36.

Levine, Lee I. (2002), Jerusalem: Portrait of the City in the Second Temple Period (538 B.C.E. - 70 C.E.) (Philadelphia: JPS).

Lewis, Theodore J. (1989), Cults of the Dead in Ancient Israel and Ugarit (HSM 39; Atlanta: Scholars).

Lipiński, Edouard (1999), 'Light רור', in van der Toorn, Becking and van der Horst, 518.

-(2006), On the Skirts of Canaan in the Iron Age: Historical and Topographical Researches (OLA 153; Leuven: Peeters).

-(2012), 'Dagān, the Master of Ploughing', in T. Boiy et al (eds), The Ancient Near East, A Life: Festschrift Karel van Lerberghe (OLA 220; Leuven: Peeters), 335-44.

Lipschits, Oded (2005), The Fall and Rise of Jerusalem: Judah under Babylonian Rule (Winona Lake: Eisenbrauns).

-(2010), 'Persian Period Finds from Jerusalem: Facts and Interpretations', JHS 9: 1-30.

Lipschits, Oded and Manfred Oeming (eds) (2006), Judah and the Judeans in the Persian Period (Winona Lake: Eisenbrauns).

Lipschits, Oded, Gary N. Knoppers and Manfred Oeming (eds) (2011), Judah and the Judeans in the Achaemenid Period: Negotiating Identity in an International Context (Winona Lake: Eisenbrauns).

Loeff, Adrianus (1887), Bijbel voor de jeugd (Dordrecht: Morks).

London, Gloria (2011), 'A Ceremonial Center for the Living and the Dead', Near Eastern Archaeology 74: 216-25.

Louw, Theo A. W. van der (2007), Transformations in the Septuagint. Towards an Interaction of Septuagint Studies and Translation Studies (CBET 47; Leuven: Peeters).

Lüdemann, Gerd (ed.) (1996), Die 'Religionsgeschichtliche Schule': Facetten eines theologischen Umbruchs (Studien und Texte zur Religionsgeschichtlichen Schule 1; Frankfurt am Main: Peter Lang).

Luhmann, Niklas (1992), Die Wissenschaft der Gesellschaft (Suhrkamp Taschenbuch Wissenschaft 1001; Frankfurt am Main: Suhrkamp).

Lundbom, Jack (2004), Jeremiah 21-36 (AncB; New York: Doubleday).

LXX.D (2010), Septuaginta Deutsch. Das griechische Alte Testament in deutscher Übersetzung. Hrsg. von Wolfgang Kraus und Martin Karrer (Stuttgart: Deutsche Bibelgesellschaft, zweite, verbesserte Auflage).

LXX.D EK (2011), Septuaginta Deutsch. Erläuterungen und Kommentare zum griechischen Alten Testament. Bd. I, II. Hrsg. von Martin Karrer und Wolfgang Kraus (Stuttgart: Deutsche Bibelgesellschaft).

MacDonald, Burton (2001), 'Climatic Changes in Jordan through Time', in MacDonald et al., 595-601.

MacDonald, Burton, Russel Adams and Piotr Bienkowski (2001), The Archaeology of Jordan (Sheffield: Academic Press).

MacDonald, Dennis R. (2001), 'Tobit and the Odyssey', in Dennis R. MacDonald, Mimesis and Intertextuality in Antiquity and Christianity (Harrisburg: Trinity Press), 11-40. 
-(2003), Does the New Testament Imitate Homer? Four Cases from the Acts of the Apostles (New Haven: Yale University Press).

MacDonald, Nathan (2012), Deuteronomy and the Meaning of 'Monotheism', 2nd edn (FAT-II/1; Tübingen: Mohr Siebeck).

-(2013), 'Monotheism', in Joel B. Green and Lee Martin McDonald (eds), The World of the New Testament: Cultural, Social, and Historical Contexts (Grand Rapids: Baker), 77-84.

Machinist, Peter (1983), 'Assyria and its Image in the First Isaiah', JAOS 103: 719-37.

Macumber, Philip G. (2001), 'Evolving landscape and Environment in Jordan', in MacDonald et al., 1-30.

Maeir, Aren M. and Carl S. Ehrlich (2001), 'Excavating Philistine Gath', BAR 27: 22-31.

Maiberger, Paul (1987-9), 'Art. paegaer', ThWAT 6: 508-14.

Maier, Christ and Dörrfuss Ernst Michael (1999), “ Um mit ihnen zu sitzen, zu essen und zu trinken”: Am 6,7; Jer 16,5 und die Bedeutung von marze $h^{a}$, ZAW 111: 45-57.

Majoros, Ferenc and Bernd Rill (2011), Das Osmanische Reich: Die Geschichte einer Grossmacht 1300-1922 (Hamburg: Nikol).

Mandell, Sara (1993), The Relationship Between Herodotus' History and the Books from Genesis until 2 Kings (Atlanta: Scholars Press).

Marböck, Johannes (1995), 'Zur frühen Wirkungsgeschichte von Ps 1', in Johannes Marböck (ed.), Gottes Weisheit unter uns: Zur Theologie des Buches Sirach (HBS 6; Freiburg: Herder), 88-100.

Margalit, Othniel (1985), 'Samson's Foxes', VT 35: 224-9.

-(1986a), 'Samson's Riddle and Samson's Magic Locks', VT 36: 225-34.

-(1986b), 'More Samson Legends', VT 36: 397-405.

-(1987), 'The Legends of Samson/Herakles', VT 37: 63-70.

Masuzawa, Tomoko (2005), The Invention of World Religions: Or, How European Universalism was Preserved in the Language of Pluralism (Chicago: University of Chicago Press).

Matoïan, Valerie et al. (2013), 'Rapport préliminaire sur les activités de la Mission Archéologique Syro-Française de Ras Shamra - Ougarit en 2009 et $2010\left(69^{\mathrm{e}}\right.$ et $70^{\mathrm{e}}$ campagnes)', Syria 90: 439-78.

Mayer, Walter (1995), 'Die historische Einordnung der 'Autobiographie' des Idrimi von Alalah', UF 27: 333-50.

Mayer-Opificius, Ruth 1981, 'Archäologischer Kommentar zur Statue des Idrimi von Alalah', UF 13: 279-90.

Mazar, Benjamin (2007), 'History of the Oasis of En-Gedi', in Ephraim Stern (ed.), En-Gedi Excavations I: Final Report (1961-1965) (Jerusalem: Israel Exploration Society), 1-5.

Mazar, Eilat (2009), The Palace of King David. Excavations at the Summit of the City of David. Preliminary Report of Seasons 2005-2007 (Jerusalem and New York: Shoham Academic Research and Publication).

McCown, Chester Carlton (ed.) (1947a), Tell en Nașbeh: Excavated under the Direction of the Late William Frederic Badè. I: Archaeological and Historical Results (Berkeley: The Palestinian Institute of Pacific School of Religion).

-(1947b), 'XIX Cult Remains', in Chester Carlton McCown (ed.), Tell en Naṣbeh: Excavated under the Direction of the Late William Frederic Badè. I: Archaeological and Historical Results (Berkeley: The Palestinian Institute of Pacific School of Religion), $233-48$.

McGeough, Kevin M. (2003), 'Locating the Marzihu Archaeologically', UF 35: 407-20. 
McGovern, Patrick E. (1992), 'Settlement Patterns of the Late Bronze and Iron Ages in the Greater Amman Area', Studies in the History and Archaeology of Jordan 4: 179-83.

McKane, William (1995), 'Micah 1,2-7', ZAW 107: 420-34.

-(1996), Jeremiah Volume II: Commentary on Jeremiah XXVI-LII (ICC; Edinburgh: T \& T Clark).

-(1998), The Book of Micah: Introduction and Commentary (Edinburgh: T \& T Clark).

McKinlay, Judith E. (1999), 'A Son is Born to Naomi: A Harvest for Israel', in Athalya Brenner (ed.), A Feminist Companion to Ruth and Esther (Sheffield: Sheffield Academic Press). 151-7.

McLaughlin, John L. (1991), 'The Marzeah at Ugarit: A Textual and Contextual Study', UF 23: 265-81.

-(2001), The Marzēah in the Prophetic Literature. References and Allusions in Light of the Extra-Biblical Evidence (VTSup 86; Leiden: Brill).

McNeile, Alan Hugh (1904), An Introduction to Ecclesiastes with Notes and Appendices (Cambridge: Cambridge University Press).

Menken, Maarten J. J. (1985), Numerical Literary Techniques in John: The Fourth Evangelist's Use of Numbers of Words and Syllables (NovTSup 55; Leiden: Brill).

-(2001), 'Scriptural Dispute between Jews and Christians in John: Literary Fiction or Historical Reality? John 9:13-17, 24-34 as a Test Case', in Reimund Bieringer, Didier Pollefeyt and Frederique Vandecasteele-Vanneuville (eds), Anti-Judaism and the Fourth Gospel (Assen: Royal Van Gorcum), 445-60.

Metzger, Bruce M. (1994), A Textual Commentary on the Greek New Testament, 2nd edn (Stuttgart: Deutsche Bibelgesellschaft).

Miller, Patrick D. (1971), 'The mrzh Text', in Loren R. Fisher (ed.), The Claremont Ras Shamra Tablets (Rome: Pontificium Institutum Biblicum), 37-48.

Minissale, Antonio (1995), La versione greca del Siracide confronto con il testo ebraico alla luce dellattività midrascica e del metodo targumico (AnBib 133; Rome: Pontifico Istituto Biblico).

Miralles Maciá, Lorena (2007), Marzeah y thíasos: Una institución convivial en el Oriente Próximo Antiguo y el Mediterráneo (Anejo XX; Madrid: Publicaciones Universidad Complutense de Madrid).

Mirjam [pseudonym of Mrs P. A. F. Steenberghe-Engeringh] s.a. (1948), Bijbelse geschiedenis: Vol. 1: De wondere geschiedenis van het volk Gods (Amsterdam: Lieverlee).

Mitchell, Hinckley G., John Merlin Powis Smith and Julius A. Bewer (1937), Critical and Exegetical Commentary on Haggai, Zechariah, Malachi and Jonah (ICC; Edinburgh: Clark).

Mittmann, S. and G. Schmitt (2001), Tübinger Atlas (Stuttgart: Deutsche Bibelgesellschaft).

Moor, Johannes C. de (1987), An Anthology of Religious Texts from Ugarit (Nisaba 16; Leiden: Brill).

-(1995), 'Standing Stones and Ancestor Worship', UF 27: 1-20.

-(1997), The Rise of Yahwism: The Roots of Israelite Monotheism, 2nd edn (BETL 91A; Leuven: Peeters).

-(2000), 'Micah 7:1-13: The Lament of a Disillusioned Prophet', in Marjo C. A. Korpel and Josef M. Oesch (eds), Delimitation Criticism: A New Tool in Biblical Scholarship (Pericope 1; Assen: Van Gorcum), 149-96.

-(2002a), 'The Structure of Micah 2:1-13: The Contribution of the Ancient Versions', in Korpel and Oesch 2002: 90-120. 
—(2002b), 'Workshop on Unit Delimitation: Micah 4:14-5:8', in Korpel and Oesch 2002: $258-75$

-(2003), 'Theodicy in the Texts of Ugarit', in Antti Laato and Johannes C. de Moor (eds), Theodicy in the World of the Bible (Leiden: Brill), 108-50.

-(2005), 'The Structure of Micah 6 in the Light of Ancient Delimitations', in Marjo C. A. Korpel and Joseph M. Oesch (eds), Layout Markers in Biblical Manuscripts and Ugaritic Tablets (Pericope, 5; Assen: Van Gorcum), 78-113.

Moor, Johannes C. de and Paul Sanders (1991), 'An Ugaritic Expiation Ritual and its Old Testament Parallels', Ugarit-Forschungen 23: 283-300.

Moore, Stephen D. and Yvonne Sherwood (2011), The Invention of the Biblical Scholar: A Critical Manifesto (Minneapolis: Fortress Press).

Morel-Payen, Lucien (1935), Les plus beaux manuscrits et les plus belles reliures de la Bibliothèque de Troyes (Troyes: J.-L. Paton).

Mulder, Samuel Israël (1844), Bijbel voor de Israëlitische jeugd, vol. 4 (Leiden: Du Mortier).

Müller, Friedrich Max (1888), Natural Religion: Inaugural Lecture Delivered Before the University of Glasgow, Nov. 14 (London: Longmans, Green and Co.).

Müller, Friedrich Max (ed.) (1879-1910), The Sacred Books of the East (50 vols; Oxford: Clarendon Press; repr. Oxford: Oxford University Press, 2001).

Müller, Hans-Peter (1986), 'Theonome Skepsis und Lebensfreude: Zu Koh 1,12-3,15', BZ 30: $1-19$.

Müller, Reinhard (2004), Königtum und Gottesherrschaft (FAT 2/3; Tübingen: Mohr Siebeck).

Muraoka, Takamitsu (2009), A Greek-English Lexicon of the Septuagint (Louvain: Peeters).

Muré, Joannes Christianus Hubertus (1863), Bijbelsche geschiedenis des Ouden en Nieuwen Testaments, vol. I/1 (Leiden: Van Leeuwen).

-(1879), Bijbelsche geschiedenis des Ouden en Nieuwen Testaments, vol. I/1 (new edn; Leiden: Van Leeuwen).

Murray, Oswyn (2009), 'The Culture of the Symposion', in Kurt A. Raaflaub and Hans van Wees (eds), A Companion to Archaic Greece (Blackwell Companions to the Ancient World, Ancient History; Chichester: Wiley-Blackwell), 508-23.

Na'aman, Nadav (1986), 'Habiru and Hebrews: The Transfer of a Social Term to the Literary Sphere', JNES 45: 271-86.

-(2004), 'Death Formulae and the Burial Place of the Kings of the House of David', Bib 85: $245-54$.

-(2005), 'The Danite Compaign Northward (Judges XVII-XVIII) and the Migration of the Phocaeans to Massalia (Strabo IV 1,4)', VT 55: 47-60.

-(2006), Ancient Israel's History and Historiography: The First Temple Period (Collected Essays 3; Winona Lake: Eisenbrauns).

- (2007), 'When and How Did Jerusalem Become a Great City? The Rise of Jerusalem as Judah's Premier City in the Eight-Seventh Century B.C.E.', BASOR 347: 21-56.

-(2009), 'Saul, Benjamin and the Emergence of "Biblical Israel", ZAW 121: 211-24, $335-49$.

-(2011), 'A Hidden Anti-Samaritan Polemic in the Story of Abimelech and Shechem (Judges 9)', BZ 55: 1-20.

Nauerth, Claudia (1985), 'Simsons Taten: Motivgeschichtliche Überlegungen', Dielheimer Blätter 21: 94-120.

Neiman, David (1948), 'PGR : A Canaanite Cult-Object in the Old Testament', JBL 67: $55-60$. 
Ngwa, Kenneth Numfor (2005), The Hermeneutics of the 'Happy' Ending in Job 42:7-17 (BZAW 354; Berlin: Walter de Gruyter).

Nichols, Deborah and Thomas H. Charlton (eds) (1998), The Archaeology of City States: Cross-Cultural Approaches (Smithsonian Series in Archaeological Inquiry; Washington DC: Smithsonian Books).

Nickelsburg, George W. E. (2001), 'Tobit, Genesis, and the Odyssey: A Complex Web of Intertextuality', in Dennis R. MacDonald (ed.), Mimesis and Intertextuality in Antiquity and Christianity (Harrisburg: Trinity Press), 41-55.

Niditch, Susan (2008), Judges (OTL; Louisville: Westminster John Knox Press).

Niehr, Herbert (1984-6), 'Art. nāśi', ThWAT 5: 647-57.

-(1994), 'Zum Totenkult der Könige von Sam'al im 9. und 8. Jahrhundert v. Chr.', SEL 11: $57-73$.

-(1999), 'Religio-Historical Aspects of the "Early Post-Exilic" Period', in Bob Becking and Marjo C. A. Korpel (eds), The Crisis of Israelite Religion: Transformation of Religious Tradition in Exilic and Post-Exilic Times (OTS 42; Leiden: Brill), 228-44. -(2001), 'Ein weiterer Aspekt zum Totenkult der Könige von Sam'al', SEL 18: 83-97.

—(2006), 'Bestattung und Ahnenkult in den Königshäusern von Sam'al (Zincirli) und Gūzāna (Tell Hạalāf) in Nordsyrien', ZDPV 122: 111-139.

-(2012a), 'Two Stelae Mentioning Mortuary Offerings from Ugarit (KTU 6.13 and 6.14)', in P. Pfälzner et al. (eds), (Re-)Constructing Funerary Rituals in the Ancient Near East. Proceedings of the First International Symposium of the Tübingen Postgraduate School 'Symbols of the Dead' in May 2009 (QSSup 1; Wiesbaden: Harrassowitz), 149-60.

-(2012b), 'Bestattung und Nachleben der Könige von Ugarit im Spiegel von Archäologie und Literatur', in A. Lang and P. Marinkovič (eds), Bios - Cultus - (Im)mortalitas: Zu Religion und Kultur - Von den biologischen Grundlagen bis zu den Jenseitsvorstellungen: Beiträge der interdisziplinären Kolloquien vom 10.-11. März 2006 und 24.-25. Juli 2009 in der Ludwig-Maximilians-Universität München (Internationale Archäologie 16; Rahden: Verlag Marie Leidorf), 145-56.

—(2013), 'Königtum und Gebet in Ugarit: Der König als Beter, das Gebet für den König und das Gebet zum König', in Alexandra Grund et al. (eds), Ich will dir danken Herr unter den Völkern: Studien zur israelitischen und altorientalischen Gebetsliteratur: Festschrift für Bernd Janowski zum 70. Geburtstag (Gütersloh: Gütersloher Verlagshaus), 603-22.

-(2014a), 'Religion', in H. Niehr (ed.), The Aramaeans in Ancient Syria (HdO I/106; Leiden: Brill), 127-203.

-(2014b), 'The Katumuwa Stele in the Context of Royal Mortuary Cult at Sam'al', in Virginia Rimmer Herrmann and J. David Schloen (eds), In Remembrance of Me: Feasting with the Dead in the Ancient Middle East (OIMP 37; Chicago: The Oriental Institute), 57-60.

-(2015), 'The King's Two Bodies: Political Dimensions of the Royal Cult of the Dead at Ugarit, Byblos and Qatna', in P. Pfälzner et al. (eds), Qatna and the Bronze Age Globalism: Akten einer internationalen Konferenz in Stuttgart im Oktober 2009 (QSSup 2; Wiesbaden: Harrassowitz) (in press).

Nielsen, Kirsten (1997), Ruth (OTL; Louisville: Westminster John Knox Press).

Nihan, Christophe (2007), From Priestly Torah to Pentateuch: A Study in the Composition of the Book of Leviticus (FAT 2/25; Tübingen: Mohr Siebeck).

Nissinen, Martti (2009), 'Wisdom as Mediatrix in Sirach 24: Ben Sira, Love, Lyrics, and Prophecy', in Mikko Luuko, Saana Svärd and Raija Mattila (eds), Of God(s), Trees, 
Kings, and Scholars: Neo-Assyrian and Related Studies in Honour of Simo Parpola (Studia Orientalia 106; Helsinki: Finnish Oriental Society), 377-90.

Noort, Edward (1988), 'Transjordan in Joshua 13: Some Aspects', in Adnan Hadidi (ed.), Studies in the History and Archeaology of Jordan III (Amman: Department of Antiquities Jordan), 125-30.

-(1994), Die Seevölker in Palästina (Palestina Antiqua; Kampen: Kok Pharos).

Noth, Martin (1948), Überlieferungsgeschichte des Pentateuch (Stuttgart: Kohlhammer).

—(1950), 'Das Amt des "Richter Israels"', in Walter Baumgartner and Otto Eissfeldt (eds), Festschrift Alfred Bertholet zum 80. Geburtstag gewidmet von Kollegen und Freunden (Tübingen: Mohr), 404-17.

-(1968), Das Zweite Buch Mose: Exodus, 4th edn (ATD 5; Göttingen: Vandenhoeck \& Ruprecht).

Nougayrol, Jean (1955), Le Palais Royal d'Ugarit III. Textes accadiens et hourrites des archives est, oust et centrales (MRS 6; Paris: Imprimerie Nationale and Librairie C. Klincksieck).

-(1968), 'Textes suméro-accadiens des archives et bibliothèques privée d'Ugarit', in Jean Nougayrol et al. (eds), Ugaritica V. Nouveaux textes accadiens, hourrites et ugaritiques des archives et bibliothèques privées d'Ugarit (MRS 16; Paris: Imprimerie Nationale and Librairie Orientaliste Paul Geuthner), 1-446.

O'Hare, Daniel (2010), "Have You Seen Son of Man?" A Study in the Translation and Vorlage of LXX Ezekiel 40-48 (SCS 57; Atlanta: SBL).

Obermann, Julian (1941), 'Votive Inscriptions from Ras Shamra', JAOS 61: 31-45.

Olmo Lete, Gregorio del (1999), Canaanite Religion According to the Liturgical Texts from Ugarit (Bethesda: CDL Press).

Onley, James (2007), The Arabian Frontier of the British Raj: Merchants, Rulers, and the British in the Nineteenth-Century Gulf (Oxford: Oxford University Press).

Oort, Abraham Johannes (1903), Kinderbijbel, naar de 'De bijbel voor jongelieden', vol. 1, 3rd edn ('s Gravenhage: Ykema).

Oosterwijk Hulshoff, Willem van (1829), De geschiedenis van Jozef voor kinderen, 10th edn (Leiden: Du Mortier; Deventer: De Lange; Groningen: Oomkes).

Oppenheim, A. Leo (1943), 'Akkadian pul(u)h(t)u and melammu', JAOS 63: 31-4.

Oswald, Wolfgang (1998), Israel am Gottesberg: Eine Untersuchung zur Literaturgeschichte der vorderen Sinaiperikope Ex 19-24 und deren historischem Hintergrund (OBO 159; Fribourg: Universitätsverlag; Göttingen: Vandenhoeck \& Ruprecht).

-(2008), Nathan der Prophet. Eine Untersuchung zu 2 Samuel 7 und 12 und 1 Könige 1 (ATANT 94; Zürich: Theologischer Verlag).

Oswalt, John N. (1986), The Book of Isaiah Chapters 1-39 (NICOT; Grand Rapids, MI: Eerdmans).

Ottley, Richard Rusden (1906), The Book of Isaiah According to the Septuagint (Codex Alexandrinus) (2 vols; Cambridge: Cambridge University Press).

Otto, Eckhart (2000), Das Deuteronomium im Pentateuch und Hexateuch: Studien zur Literaturgeschichte von Pentateuch und Hexateuch im Lichte des Deuteronomiumrahmens (FAT 30; Tübingen: Mohr Siebeck).

-(2003), 'Pentateuch', in Hans Dieter Betz, Don S, Browning, Bernd Janowski and Eberhard Jüngel (eds), Religion in Geschichte und Gegenwart, vol. IV, 4th edn (Tübingen: Mohr Siebeck), 1089-102.

Otto, Rudolf (1958), The Idea of the Holy (New York: Oxford University Press; first German original: 1923).

Ozick, Cynthia (1994), 'Ruth', in Judith A. Kates and Gail Twersky Reimer (eds), Reading 
Ruth. Comtemporary Women Reclaim a Sacred Story (New York: Ballantine Books), 211-32.

Pakkala, Juha (2009), 'The Date of the Oldest Edition of Deuteronomy', ZAW 121: 388-401.

Palumbo, Gaetano, ed. (1994), JADIS: The Jordan Antiquities Database and Information System (Amman: DoA-ACOR).

Pardee, Dennis (1996), 'Marzihu, Kispu, and the Ugaritic Funerary Cult: a Minimalist View', in Nick Wyatt, Wilfred G. E. Watson and Jeffery B. Lloyd (eds), Ugarit, Religion and Culture. Proceedings of the International Colloquium on Ugarit, Religion and Culture, Edinburgh, July 1994. Essays Presented in Honour of Professor John C. L. Gibson (UBL 12; Münster: Ugarit Verlag), 273-87.

-(2003), 'Ilu on a Toot (RS 24.258)', in William W. Hallo and K. Lawson Younger (eds), The Context of Scripture. Vol 1: Canonical Compositions from the Biblical World (Leiden: Brill), 302-5.

Parker, Bradley J. (2001), The Mechanics of Empire: The Northern Frontier of Assyria as a Case Study in Imperial Politics (Helsinki: The Neo-Assyrian Text Corpus Project).

Parker, Simon B. (1997), 'Aqhat', in S. B. Parker (ed.), Ugaritic Narrative Poetry (SBL Writings from the Ancient World 9; Atlanta: Scholars Press), 49-80.

Patte, Daniel (1975), Early Jewish Hermeneutic in Palestine (SBLDS 22; Missoula: SBL/ Scholars Press).

Pearce, Laurie E. (2006), 'New Evidence for Judeans in Babylonia', in Oded Lipschits and Manfred Oeming (eds), Judah and the Judeans in the Persian Period (Winona Lake, IN: Eisenbrauns), 399-411.

Peetz, Melanie (2008), Abigajil, die Prophetin: Mit Klugheit und Schönheit für Gewaltverzicht: Eine exegetische Untersuchung zu 1 Sam 25 (FzB 116; Würzburg: Echter).

Perl, Jeffrey M. and Andrew P. Tuck (1985), 'The Hidden Advantage of Tradition: On the Significance of T.S. Eliot's Indic Studies', Philosophy East and West 35/2: 116-31.

Peters, Norbert (1913), Das Buch Jesus Sirach oder Ecclesiasticus (EHAT 25; Münster: Aschendorff).

Petersen, D. L. (1985), Haggai and Zechariah 1-8: A Commentary (OTL; London: SCM).

Petit, Lucas Pieter (2009), Settlement Dynamics in the Middle Jordan Valley during Iron Age II (BAR Int. Ser. 2033; Oxford: Archaeopress).

Pettazzoni, Raffaele (1955), Lonniscienza di Dio (Torino: Einaudi).

Pinker, Aron (2010), 'How Should We Understand Ecclesiastes 2:16?', JBQ 38/4: 219-29. Pope, Marvin H. (1977), Song of Songs: A New Translation with Introduction and Commentary (AB 7C; Garden City, NY: Doubleday).

Prag, Kay (1998), 'A Response from the "Plains of Moab"', in Shmuel Ahituv and Eliezer D. Oren (eds), The Origin of Early Israel - Current Debate (Beer-Sheva 7; Beer-Sheva: Beer-Shevah University).

Preuß, Horst Dietrich (1994-6), 'Art. tô 'ebāh', in ThWAT 8: 579-92.

Priest, John F. (1985), 'The Dog in the Manger: In Quest of a Fable', The Classical Journal 81: 49-58.

Pritchard, James B. (1961), The Water System of Gibeon (Museum Monographs; Philadelphia: The University Museum).

Rad, Gerhard von (1960), Theologie des Alten Testaments. Band 1. Die Theologie der geschichtlichen Überlieferungen (München: Kaiser). 
—(1968), Das fünfte Buch Mose: Deuteronomium, übersetzt und erklärt (ATD; Göttingen: Vandenhoeck \& Ruprecht; second printing).

Rainey, Anson F. (2001), 'Israel in Merenptah's Inscription and Reliefs', IEJ 51: 57-75.

Ralph, Edith s.a. (c. 1895), Stap voor stap door den Bijbel: De bijbelsche geschiedenis aan kinderen verhaald, naar het Engelsch door Christine (Amsterdam: Dusseau).

Ramusack, Barbara N. (2004), The Indian Princes and Their States (The New Cambridge History of India 3/6; Cambridge: Cambridge University Press).

Rappold, Frederika Willemina (1925), Vertellingen uit den Bijbel: Geschiedenis van het Israëlietische Volk (Amsterdam: Meulenhoff).

Redford, Donald B. (1982a), 'A Bronze Age Itinerary in Transjordan (Nos 89-101 of Thutmose III's List of Asiatic Toponyms)', JSSEA 12: 55-74.

-(1982b), 'Contact between Egypt and Jordan in the New Kingdom: Some Comments on Sources', in A. Hadidi (ed.), Studies in the History and Archaeology of Jordan I (Amman: Department of Antiquities Jordan), 119-55.

-(1992), Egypt, Canaan, and Israel in Ancient Times (Princeton, NJ: Princeton University Press).

Reich, Ronny (2004), 'Raymond Weill's Excavations in the City of David (1913-1914) - a Reassessment', in Hershel Shanks (ed.), The City of David. Revisiting Early Excavations: English Translations of Reports by Raymond Weill and L.-H. Vincent (Washington, DC: Biblical Archaeological Society), 123-52.

-(2011), Excavating the City of David: Where Jerusalem's History Began (Jerusalem: Israel Exploration Society - Biblical Archaeology Society).

Reich, Ronny and Eli Shukron (2003), 'The Urban Development of Jerusalem in the Late Eighth Century B.C.E.', in Vaughn and Killebrew, 209-18.

Reicke, Bo (1967), 'Liturgical Traditions in Mic. 7', HTR 60: 349-67.

Reimer, Andy M. (2013), 'The Man Born Blind: True Disciple of Jesus', in Hunt et al., $428-38$.

Reinmuth, Titus (2002), Der Bericht Nehemias: Zur literarischen Eigenart, traditionsgeschichtlichen Prägung und innerbiblischen Rezeption des Ich-Berichts Nehemias (OBO 183; Fribourg: University Press; Göttingen: Vandenhoeck \& Ruprecht).

Reitemeyer, Michael (2000), Weisheitslehre als Gotteslob. Psalmentheologie im Buch Jesus Sirach (BBB 127; Bonn: Philo).

Renaud, Bernard (1977), La formation du livre de Michée: Tradition et Actualisation (Études bibliques; Paris: Gabalda).

-(1987), Michée - Sophonie, Nahum (Sources bibliques; Paris: Lecoffre/Gabalda).

Renkema, Johan (1998), Lamentations (HCOT; Leuven: Peeters).

Renz, Johannes and Wolfgang Röllig (1995), Handbuch der althebräischen Epigraphik, Bd. 1 (Darmstadt: Wissenschaftliche Buchgesellschaft).

Reymond, Eric D. (2007), 'Sirach 51:13-30 and 11Q5 (= 11QPS ) 21.11-22.1', RdQ 23: $207-31$.

Richards, John F. (1993), The Mughal Empire (The New Cambridge History of India 1, The Mughals and their Contemporaries 5; New Delhi: Cambridge University Press).

Roberts, Jim J. M. (2003), 'Egypt, Assyria, Isaiah, and the Ashdod Affair', in Vaughn and Killebrew, 265-83.

Robinson, Ronald (1972), 'Non-European Foundations of European Imperialism. Sketch for a Theory of Collaboration', in Roger Owen and Bob Sutcliffe (eds), Studies in the Theory of Imperialism (London: Longman), 117-42.

Römer, Thomas (1998), 'Why Would the Deuteronomists Tell about the Sacrifice of Jephthah's Daughter?', JSOT 77: 27-38. 
-(2002) 'Das Buch Numeri und das Ende des Jahwisten: Anfragen zur

"Quellenscheidung « im vierten Buch des Pentateuch', in Jan Christian Gertz, Konrad Schmid and Markus Witte (eds), Abschied vom Jahwisten: Die Komposition des Hexateuch in der jüngsten Diskussion (BZAW 315; Berlin and New York: Walter de Gruyter), 215-31.

-(2013), 'La loi du roi en Deutéronome 17 et ses fonctions', in Olivier Artus (ed.), Loi et Justice dans la Littérature du Proche-Orient Ancien (Wiesbaden: Harrassowitz), 99-111.

Römer, Thomas and Marc Brettler (2000), 'Deuteronomy 34 and the Case for a Persian Hexateuch', JBL 119: 401-19.

Roolfs, Mathilde (1984), Verhalen over God, de mensen en de wereld: Tora en Profeten, 2nd edn (Amsterdam and Brussels: Van Goor).

Rover, Piet Adriaan de s.a. (1942), Naar 't heilig blad: Bijbelvertelling en -verklaring voor de rijpere jeugd, vol. 1 (Wageningen: Veenman).

Rowlands, Michael, Mogens Larsen and Kristian Kristiansen (1990), Centre and Periphery in the Ancient World (First published 1987; Cambridge: Cambridge University Press).

Rudolph, Wilhelm (1968), Jeremia (HAT; Tübingen: J. C. B. Mohr; third printing).

Russell, Malcolm B. (1985), The First Modern State: Syria under Faysal, 1918-1920 (Studies in Middle Eastern History 7; Minneapolis, MI: Bibliotheca Islamica).

Ryssel, Victor (1887), Die Textgestalt und die Echtheit des Buches Micha: Ein kritischer Commentar zu Micha (Leipzig: Hirzel).

Sack, Ronald H. (1972), Amel-Marduk 562-560 B.C.: A Study Based on Cuneiform, Old Testament, Greek, Latin, and Rabbinical Sources (AOAT 4; Neukirchen-Vluyn: Neukirchener Verlag).

—(1994), Neriglissar - King of Babylon (AOAT 236; Kevelaer: Butzon \& Bercker; Neukirchen-Vluyn: Neukirchener).

-(2003), 'Nebuchadnezzar II and the Old Testament: History versus Ideology', in Oded Lipschits and Joseph Blenkinsopp (eds), Judah and the Judeans in the Neo-Babylonian Period (Winona Lake, IN: Eisenbrauns), 221-33.

Sæbø, Magne (ed.) (2008), Hebrew Bible/Old Testament: The History of its Interpretation. Vol. II: From the Renaissance to the Enlightenment (Göttingen: Vandenhoeck \& Ruprecht).

Sakenfeld, Katharine Doob (1999), Ruth (Interpretation; Louisville: John Knox Press).

Sander, Hans-Joachim (2013), 'Der ewige Gott hat Raum. Theologie im spatial turn', TRev 109: 91-110.

Sanders, James A. (1965), The Psalms Scroll of Qumrân Cave 11 (11QPs ${ }^{a}$ ) (DJD 4; Oxford: Clarendon), 79-85.

Sandmel, Samuel (1962), 'Parallelomania', JBL 81: 1-13.

Sasson, Jack M. (1979), Ruth: A New Translation with a Philological Commentary and a Formalist-Folklorist Interpretation, Second Edition with Corrections (Sheffeld: Continuum).

Schäfer, Gerd (1974), "König der Könige" - "Lied der Lieder" (Heidelberg: Winter).

Schart, Anton and Jutta Krispenz (eds), Die Stadt im Zwölfprophetenbuch (BZAW, 428; Berlin: De Gruyter).

Schaudig, Hanspeter (2001), Die Inschriften Nabonids von Babylon und Kyros' des Grossen samt den in ihrem Umfeld entstandenen Tendenzschriften: Textausgabe und Grammatik (AOAT 256; Münster: Ugarit-Verlag).

Schechter, Solomon and Charles Taylor (1899), The Wisdom of Ben Sira: Portions of 
the Book of Ecclesiasticus from Hebrew Manuscripts in the Cairo Genizah Collection (Cambridge: Cambridge University Press).

Schenker, Adrian (2011), 'Gibt es eine graeca veritas für die hebräische Bibel?', in Adrian Schenker (ed.), Anfänge der Textgeschichte des Alten Testaments. Studien zu Entstehung und Verhältnis der frühesten Textformen (BWANT 194; Stuttgart: Kohlhammer), $177-200$.

Schiphorst, Franciscus Xaverus Maria (1950), Bijbelse geschiedenis voor het katholieke gezin (Bilthoven: Nelissen; Antwerpen: 't Groeit).

Schmid, Konrad (1999), Erzväter und Exodus: Untersuchungen zur doppelten Begründung der Ursprünge Israels innerhalb der Geschichtsbücher des Alten Testaments (WMANT 81; Neukirchen-Vluyn: Neukirchener Verlag).

Schmidt, Brian B. (1994), Israel's Beneficent Dead: Ancestor Cult and Necromancy in Ancient Israelite Religion and Tradition (FAT 11; Tübingen: Mohr Siebeck).

Schmitt, Rüdiger. (2003), 'Gab es einen Bildersturm nach dem Exil? Einige Bemerkungen zur Verwendung von Terrakottafigurinen im nachexilischen Israel', in R. Albertz and B. Becking (eds), Yahwism after the Exile: Perspectives on Israelite Religion in the Persian Era (Proceedings EABS 2000) (STAR 5; Leiden: Brill), 186-98.

Schneiders, Sandra M. (2002), 'To See or Not to See: John 9 as a Synthesis of the Theology and Spirituality of Discipleship', in John Painter, R. Alan Culpepper and Fernando F. Segovia (eds), Word, Theology, and Community in John (Fs Robert Kysar; St Louis, MO: Chalice), 189-209.

Schnutenhaus, Frank (1964), 'Das Kommen und Erscheinen Gottes im Alten Testament', ZAW 76: 1-22.

Schoors, Antoon (2003), 'Theodicy in Qohelet', in Antti Laato and Johannes C. de Moor (eds), Theodicy in the World of the Bible (Leiden: Brill), 375-409.

-(2004), The Preacher Sought to Find Pleasing Words: A Study of the Language of Qohelet, Part II: Vocabulary (Leuven: Peeters).

-(2013), Ecclesiastes (HCOT; Leuven: Peeters).

Schorch, Stefan (2003), 'Die Propheten und der Karneval: Marzeach - Maioumas Maimuna', VT 53: 397-415.

Schwarz, Günther (1970), “ ... das Licht Israels”? Eine Emendation', ZAW 82: 447-8.

Schwemer, Daniel (2001), Die Wettergottgestalten Mesopotamiens und Nordsyriens im Zeitalter der Keilschriftkulturen (Wiesbaden: Harrassowitz).

Schwiderski, Dirk (2000), Handbuch des nordwestsemitischen Briefformulars: Ein Beitrag zur Echtheitsfrage der aramäischen Briefe des Esrabuches (BZAW 295; Berlin/New York: De Gruyter).

Selman, Martin J. (1996), 'אור', in Willem A. VanGemeren (ed.), New International Dictionary of Old Testament Theology and Exegesis, vol. 1 (Carlisle: Paternoster), 324-9.

Selms, Adrianus van (1974), Jeremia deel II (POT; Nijkerk: Callenbach).

Seow, Choon-Leong (2013), Job 1-21: Interpretation and Commentary (Illuminations; Grand Rapids: Eerdmans).

Sepp, Alidus Anne s.a. (1925), Bijbelsche geschiedenis met plaatjes, Vol. 1: Oude Testament, 2nd edn (Hillegom: Editio).

Seux, M. Joseph (1967), Épithètes royales akkadiennes et sumériennes (Paris: Letouzey et Ané).

Shanks, Hershel (1999), 'Everything You Ever Knew about Jerusalem is Wrong (Well, Almost)', BAR 25/6: 20-9. 
-(2007), 'Assyrian Palace Discovered in Ashdod', BAR 33/1: 56-60.

Sherwood, Yvonne (2013), 'Beyond "Reception History": Staging the Disaster of the Spanish Conquest on the Stage of Jeremiah', Paper delivered at IOSOT Conference Munich.

Shveka, Avi Shveka and Pierre Van Hecke (2014), 'The Metaphor of Criminal Charge as a Paradigm for the Conflict between Job and His Friends', Ephemerides Theologicae Lovanienses 90: 99-119.

Skehan, Patrick W. (1979), 'Structures in Poems on Wisdom: Proverbs 8 and Sirach 24', CBQ 41: 365-79.

Skehan, Patrick W. and Alexander A. Di Lella (1987), The Wisdom of Ben Sira (AB 39; New York: Doubleday).

Sleeman, Matthew (2013), 'Critical Spatial Theory 2.0', in Gert T. M. Prinsloo and Christl M. Maier (eds), Constructions of Space V: Place, Space and Identity in the Ancient Mediterranean World (LHBOTS 576; London: Bloomsbury), 49-66.

Smelik, Klaas (2000), Ruth (Verklaring van de Hebreeuwse Bijbel; Kampen: Kok).

-(2004), 'The Function of Jeremiah 50 and 51 in the Book of Jeremiah', in Martin Kessler (ed.), Reading the Book of Jeremiah: A Search for Coherence (Winona Lake, IN: Eisenbrauns), 87-98.

-(2014), 'Eyewitness Accounts in the Book of Samuel? A Reappraisal', in Klaas Smelik and Karolien Vermeulen (eds), Approaches to Literacy Readings of Ancient Jewish Writings (SSN 62; Leiden: Brill), 77-97.

Smith, Lesley M. (1996), Medieval Exegesis in Translation: Commentaries on the Book of Ruth (Kalamazoo: Western Michigan University).

Smith, Mark S. (2001), The Origins of Biblical Monotheism: Israel's Polytheistic Background and the Ugaritic Texts (Oxford: Oxford University Press).

Snaith, John G. (1967), 'Biblical Quotations in the Hebrew of Ecclesiasticus', JTS 19: 1-12.

Soden, Wolfram von (1936), 'Leistung und Grenze sumerischer und babylonischer Wissenschaft', Die Welt als Geschichte 2: 411-64, 509-57.

-(1960), 'Licht und Finsternis in der sumerischen und babylonischen Religion', Studium Generale 13: 647-53.

Soldt, Wilfred Hugo van (1991), Studies in the Akkadian of Ugarit. Dating and Grammar (AOAT 40; Kevelaer: Butzon \& Bercker; Neukirchen-Vluyn: Neukirchener Verlag).

-(2010), 'The Akkadian Legal Texts from Ugarit', in Sophie Démaire-Lafont and André Lemaire (eds), Trois millénaires de formulaires juridiques. Sciences Historiques et Philologiques (Hautes études orientales 48; Moyen et Proche-Orient 4; Genève: Droz), $85-124$.

Southwood, Katherine E. (2012), Ethnicity and the Mixed Marriage Crisis in Ezra 9-10: An Anthropological Approach (Oxford Theological Monographs; Oxford: Oxford University Press).

Spalinger, Anthony (1992), '3d Intermediate-Saite Period (Dyn. 21-26)', in David Noel Freedman et al. (eds), The Anchor Bible Dictionary. Volume 2 (New York: Doubleday), $353-64$.

Sparnaaij, C. (1911), De Bijbel aan kinderen verteld, Vol. 1: Het Oude Testament (Baarn: Hollandia).

Spender, Stephen (1986), Eliot (Glasgow: Fontana Paperbacks).

Spiegel, Shalom (1945), 'Noah, Danel, and Job: Touching on Canaanite Relics in the Legends of the Jews', in Louis Ginzberg. Jubilee Volume on the Occasion of His Seventieth Birthday. English Section (New York: American Academy of Jewish Research), 305-55. 
Spronk, Klaas (1986), Beatific Afterlife in Ancient Israel and in the Ancient Near East (AOAT 219; Kevelaer: Butzon \& Bercker; Neukirchen-Vluyn: Neukirchener Verlag). -(2010), 'The Book of Judges as a Late Construct', in Louis Jonker (ed.), Historiography and Identity: (Re)Formulation in Second Temple Historiographical Literature (New York: T \& T Clark), 15-28.

Stade, Bernhard (1881), 'Bemerkungen über das Buch Micha', ZAW 1: 161-72.

-(1883), 'Weitere Bemerkungen zu Micha 4.5', ZAW 3: 1-16.

-(1903), 'Streiflichter auf die Entstehung der jetzigen Gestalt der alttestamentlichen Prophetenschriften, 4. Micha 1.2-4; 5. Micha 7.7-20, ein Psalm', ZAW 23: 153-71.

Staples, William E. (1937), 'The Book of Ruth', American Journal of Semitic Languages and Literatures 53: 145-57.

Stausberg, Michael (2007), 'The Study of Religion(s) in Western Europe (I): Prehistory and History until World War II', Religion 37: 294-318.

-(2008), 'The Study of Religion(s) in Western Europe (II): Institutional Developments after World War II', Religion 38: 305-18.

-(2009), 'The Study of Religion(s) in Western Europe (III): Further Developments after World War II', Religion 39: 261-82.

Stavrakopoulou, Francesca (2006), 'Exploring the Garden of Uzza: Death, Burial and Ideologies of Kingship', Bib 87: 1-21.

Steck, Odil Hannes (1985), Bereitete Heimkehr: Jesaja 35 als redaktionelle Brücke zwischen dem Ersten und dem Zweiten Jesaja (SBS 121; Stuttgart: Katholisches Bibelwerk).

Steen, Eveline J. van der (1996), 'The Central East Jordan Valley in the Late Bronze and Early Iron Ages', BASOR 302: 51-70.

-(2002/2004), Tribes and Territories in Transition. The Central East Jordan Valley and Surrounding Regions in the Late Bronze and Early Iron Ages: A Study of the Sources (diss. Groningen $)=($ OLA 130; Leuven: Peeters $)$.

Stern, Ephraim (1976), 'Bes Vases from Palestine and Syria', IEJ 26/4: 183-87, plates 32-3.

-(1982), Material Culture of the Land of the Bible in the Persian Period 538-332 B.C. (trans. Essa Cindorf; Jerusalem: Israel Exploration Society; Warminster: Aris \& Philips).

- (1984), 'The Archaeology of Persian Palestine', in William D. Davies and Louis Finkelstein (eds), The Cambridge History of Judaism. Volume 1: Introduction; The Persian Period (Cambridge: Cambridge University Press), 88-114 (reprinted 2003 et passim).

-(1999), 'Religion in Palestine in the Assyrian and Persian periods', in Bob Becking and Marjo C. A. Korpel (eds), 245-55.

-(2006), 'The Religious Revolution in Persian-Period Judah', in Oded Lipschits and Manfred Oeming (eds), 199-205.

-(2007), En-Gedi Excavations I: Final Report (1961 - 1965) (Jerusalem: Israel Exploration Society).

Stern, Ephraim and Svetlana Matskevich (2007), 'Stratigraphy of Stratum IV', in Ephraim Stern (ed.), En-Gedi Excavations I: Final Report (1961-1965) (Jerusalem: Israel Exploration Society), 193-7.

Steuernagel, Carl (1912), Lehrbuch der Einleitung in das Alte Testament: mit einem Anhang über die Apokryphen und Pseudepigraphen (Tübingen: Mohr).

Stipp, Hermann-Josef (1994), Das masoretische und alexandrinische Sondergut des Jeremiabuches: Textgeschichtlicher Rang, Eigenarten, Triebkräfte (OBO 136; Freiburg/ Göttingen: Universitätsverlag/Vandenhoeck \& Ruprecht).

Stolz, Fritz (1996), Einführung in den biblischen Monotheismus (Die Theologie: 
Einführungen in Gegenstand, Methoden und Ergebnisse ihren Disziplinen und Nachbarwissenschaften; Darmstadt: Wissenschaftliche Buchgesellschaft).

-(1998), 'Der Gott der Theologie und die Götter der Religionswissenschaft', in Ingo U. Dalferth, Hans Jürgen Luibl and Hans Weder (eds), Die Wissenschaften und Gott: Ringvorlesung aus Anlass des 60. Geburtstages des Rektors der Universität Zürich, Prof. Dr. Hans Heinrich Schmid (Theophil 9; Zürich: Pano), 155-73; repr. in Daria PezzoliOlgiati et al. (eds), Religion und Rekonstruktion: Ausgewählte Aufsätze (Göttingen: Vandenhoeck \& Ruprecht, 2004), 287-304.

Stone, Elizabeth (1997), 'City-States and their Centres: The Mesopotamian Example, in Deborah L. Nichols and Thomas H. Charlton(eds), The Archaeology of City States: Cross-Cultural Approaches (Smithsonian Series in Archaeological Inquiry; Washington/London: Smithsonian), 15-26.

Strange, John (2001), 'The Late Bronze Age', in MacDonald et al., 291-321.

-(2009), 'Tall al-Fukhar 1990-1993 and 2002', Studies in the History and Archaeology of Jordan 10: 611-15.

Suriano, Matthew J. (2009), 'Dynasty Building at Ugarit: The Ritual and Political Context of KTU 1.161', AulOr 27: 105-23.

-(2010a), 'A Place in the Dust: Text, Topography and a Toponymic Note on Micah 1:10-12a', VT 60: 433-46.

-(2010b), The Politics of Dead Kings. Dynastic Ancestors in the Book of Kings and Ancient Israel (FAT II/48; Tübingen: Mohr Siebeck).

Sweeney, Marvin A. (1996), Isaiah 1-39 with an Introduction to Prophetic Literature (FOTL 16; Grand Rapids, MI: Eerdmans).

Tadmor, Hayim (2007), The Inscriptions of Tiglath-pileser III King of Assyrian. Critical Edition, with Introductions, Translations and Commentary, with Addenda et Corrigenda (Repr. of 1994 edn; Jerusalem: The Israel Academy of Sciences and Humanities).

Thalmann, Jean-Paul (1990), 'Beth-Shan satellite en Égypte', Monde Biblique 66: 2-10.

Thompson, Henry O. (1992), 'Jordan River', in David Noel Freedman (ed.), The Anchor Bible Dictionary, vol. 3 (New York: Doubleday), 953-8.

Thompson, John (1987), The Book of Jeremiah (NICOT; Grand Rapids, MI: Eerdmans; second printing).

Tigay, Jeffrey (1982), The Evolution of the Gilgamesh Epic (Phildelphia: University of Pennsylvania; reprint 2002).

Toorn, Karel van der (1996), Family Religion in Babylonia, Syria, and Israel (Leiden: Brill).

-(ed.) (1997), The Image and the Book: Iconic Cults, Aniconism, and the Rise of Book Religion in Israel and the Ancient Near East (CBET 21; Leuven: Peeters).

-(2003), 'Theodicy in Akkadian Literature', in Antti Laato and Johannes C. de Moor (eds), Theodicy in the World of the Bible (Leiden: Brill), 57-89.

-(2007), Scribal Culture and the Making of the Hebrew Bible (Cambridge: Harvard University Press).

Toorn, Karel van der, Bob Becking and Pieter W. van der Horst (eds) (1999), Dictionary of Deities and Demons in the Bible, 2nd rev. edn (Leiden: Brill; Grand Rapids: Eerdmans).

Toury, G. (1995), Descriptive Translation Studies and Beyond (BTL 4; Amsterdam and Philadelphia: Benjamins Translation Library).

Trenchard, Warren C. (1982), Ben Sira's View of Women: A Literary Analysis (BJS 38; Chico: Scholars Press).

Treves, Marco (1956), 'Studi su Gesù ben Sirach', La Rassegna Mensile di Israel 22: 387-97. Trompf, Garry W. (1979a), 'Notions of Historical Recurrence', in John A. Emerton 
(ed.), Studies in the Historical Books of the Old Testament (VTSup 30; Leiden: Brill), 213-29.

-(1979b), The Idea of Historical Recurrence in Western Thought (Berkeley: University of California Press).

Troxel, Ronald L. (2008), LXX-Isaiah as Translation and Interpretation: The Strategies of the Translator of the Septuagint of Isaiah (JSJSup 124; Leiden: Brill).

Tsevat, Matitiahu (1980), 'The Meaning of the Book of Job', in The Meaning of the Book of Job and Other Biblical Studies (New York: Ktav), 1-37 (reprinted from HUCA 37 [1966], 73-106).

Tubb, Jonathan N. (1988), 'Tell es-Sa'idiyeh: Preliminary Report on the First Three Seasons of Renewed Excavations, 1988', Levant 20: 23-89.

Tur-Sinai, Naftali Herz (1961), 'A Contribution to the Understanding of Isaiah i-xii', in C. Rabin (ed.), Studies in the Bible (ScrH 8; Jerusalem: Magnes), 154-88.

Tylor, Edward B. (1871), Primitive Culture: Researches into the Development of Mythology, Philosophy, Religion, Art, and Custom (London: John Murray).

Uehlinger, Christoph (1997), 'Anthropomorphic Cult Statuary in Iron Age Palestine and the Search for Yahweh's Cult Images', in Van der Toorn 1997: 97-155.

-(1998), “... und wo sind die Götter von Samarien?”: Die Wegführung syrischpalästinischer Kultstatuen auf einem Relief Sargons II. in Ḥorșābād/Dūr- Šarrukīn', in M. Dietrich and I. Kottsieper (eds), 'Und Mose schrieb dieses Lied auf': Studien zum Alten Testament und zum Alten Orient (Fs Oswalt Loretz; AOAT 250; Münster: UgaritVerlag), 739-76.

-(2001), 'Perserzeitliche Reiterfigur', in Othmar Keel and Thomas Staubli (eds), "Im Schatten Deiner Flügel": Tiere in der Bibel und im alten Orient (Fribourg: Bibel + Orient Museum), 40-1.

-(2003), "Hat Yнwh denn wirklich nur mit Mose geredet?" Biblische Exegese zwischen Religionsgeschichte und Theologie, am Beispiel von Num 12', BZ 44: 230-59.

-(2010), 'Religionswissenschaft in der Schweiz: Geschichte und aktuelle Perspektiven', Bulletin der Vereinigung der Schweizerischen Hochschuldozierenden 36/1: 5-12.

Ulfers, Siebold s.a. (1889), De bijbelsche geschiedenis aan kinderen verhaald (Rotterdam: Bolle).

Ussishkin, David (2004), 'Hebrew Inscriptions, Section B: The Royal Judean Storage Jars and Seal Impressions from the Renewed Excavations', in David Ussishkin (ed.), The Renewed Archaeological Excavations at Lachish (1973-1994) (Tel Aviv: Tel Aviv University), 2133-47.

-(2007), 'Megiddo and Samaria: A Rejoinder to Norma Franklin', BASOR 348: 49-70.

-(2009), 'The Temple Mount in Jerusalem During the First Temple Period: An Archaeologist's View', in D. Schloen (ed.), Exploring the Longue Durée: Essays in Honor of Lawrence E. Stager (Winona Lake: Eisenbrauns), 473-83.

Utzschneider, Helmut (2005), Micha (ZBK.AT 24/1; Zürich: Theologischer Verlag).

Valkama, Kirsi (2012), Judah in the Mid-Sixth Century BCE: Archaeological Evidence for a Post-Collapse Society (Helsinki: University of Helsinki).

Van Campen, Abraham Willem (1857), De Bijbel voor jeugdige christenen: Godsdienstig huisboek (Tiel: Campagne).

Van der Palm, Johannes Henricus (1820), Bijbel voor de jeugd, vol. 4, 2nd edn (Leiden: Du Mortier).

Van Seters, John (1983), In Search of History: Historiography in the Ancient World and the Origins of Biblical History (New Haven: Yale University Press).

-(1988), 'The Primeval Stories of Greece and Israel Compared', ZAW 100: 2-22. 
-(1994), The Life of Moses. The Yahwist as Historian in Exodus-Numbers (Louisville, KY: Westminster/John Knox).

Vaughn, Andrew G. and Ann E. Killebrew (eds) (2003), Jerusalem in Bible and Archaeology: The First Temple Period (SBLSS 18; Atlanta: SBL).

Vaux, Roland de (1971), Histoire ancienne d'Israel: Des origins à installation en Canaan (Paris: Libraire Lecoffre).

Veenhof, Klaas (2001), Geschichte des Alten Orients bis zur Zeit Alexanders des Großen (GAT 11; Göttingen: Vandenhoeck \& Ruprecht).

Veijola, Timo (1977), Das Königtum in der Beurteilung der deuteronomistischen Historiographie: Eine redaktionsgeschichtliche Untersuchung (AASFB 198; Helsinki: Suomalainen Tiedeakatemia).

-(1990), David. Gesammelte Studien zu den Davidüberlieferungen des Alten Testaments (Schriften der Finnischen exegetischen Gesellschaft 52; Helsinki/Göttingen: Finnische Exegetische Gesellschaft/Vandenhoeck \& Ruprecht).

-(2007), 'Das Opfer des Abraham - Paradigma des Glaubens aus dem nachexilischen Zeitalter', in Timo Veijola (ed.), Offenbarung und Anfechtung: Hermeneutisch-theologische Studien zum Alten Testament (BThSt 89; Neukirchen-Vluyn: Neukirchener), 88-133.

Vernet, André et al. (eds) (1997), Le bibliothèque de l'Abbaye de Claivauz du XII au XVIII siècle (Documents, Études et Répertoires publiés par l'Institut de Recherche et d'Histoire des Textes), tome 2: Les manuscrits conservés, Première partie: Manuscrits bibliques patristiques et théologiques (Paris: CNRS Éditions).

Vieweger, Dieter (2011), 'The Transition from the Bronze to the Iron Age in Northern Palestine, Archaeological and Archaeometric Investigations on Tall Zirāa’, Ägypten und Levante 21: 305-17.

Vieweger, Dieter and Jutta Häser (2007), 'Tall Zira'a. Five Thousand Years of Palestinian History on a Single-Settlement Mound', Near Eastern Archaeology 70: 147-67.

-(2010), 'Das “Gadara Region Project": Der Tell Zerāa in den Jahren 2007 bis 2009', ZDPV 126: 1-28.

Virolleaud, Charles (1951), 'Six textes de Ras Shamra provenant de la XIVe campagne (1950)', Syria 28: 163-79.

Volz, Paul (1922), Der Prophet Jeremia übersetzt und erklärt (KAT; Leipzig and Erlangen: A. Deichertsche Verlagsbuchhandlung).

Wagenaar, Jan A. (2001), Judgement and Salvation: The Composition and Redaction of Micah 2-5 (VTSup 85; Leiden: Brill).

Wagner, Peter (1994), Die Entwicklung der Sakralarchitektur in Nordsyrien und Südostkleinasien vom Neolithikum bis in das 1. Jt. v. Chr. (MUS XV) (München: Profil Verlag).

Wagner, Volker (2004-7), 'Die Rolle Bethlehems in Mi 5,1-5', ZAH 17-20: 197-217.

Wajdenbaum, Philippe (2011), Argonauts of the Desert: Structural Analysis of the Hebrew Bible (Copenhagen International Seminar; Sheffield: Equinox).

Waltke, Bruce K (2007), A Commentary on Micah (Grand Rapids: Eerdmans).

Wambacq, Benjamin (1957), Jeremias/Klaagliederen/Baruch/Brief van Jeremias uit de grondtekst vertaald en uitgelegd (BOT; Roermond and Maaseik: Romen).

Ward, William A. (1973), 'A Possible New Link between Egypt and Jordan during the Reign of Amenhotep III', ADAJ 18 (1973), 45-6, Plate XXVII 1-3.

Wartke, Ralf-B. (2005), Sam'al: Ein aramäischer Stadtstaat des 10. bis 8. Jahrhunderts v. Chr. und die Geschichte seiner Erforschung (Mainz: Vorderasiatisches Museum, Von Zabern).

Waterfield, Robin (2010), Polybius, The Histories (Oxford: Oxford University Press). 
Weidner, Ernst F. (1939), 'Jojachin, König von Juda, in babylonischen Keilschrifttexten', in Mélanges syriens offerts à René Dussaud; secrétaire perpétuel de l'Académie des Inscriptions et Belles-Lettres par ses amis et ses élèves, vol. 2 (Bibliothèque archéologique et historique 30, 2 vols; Paris: Geuthner), 923-35.

Weill, Raymond (1920), La cité de David. Compte rendu des fouilles exécutées, à Jerusalem, sur le site de la ville primitive: Campagne 1913-1914 (Paris: Geuthner).

Weippert, Helga (1988), Palästina in vorhellenistischer Zeit (Handbuch der Archäologie Vorderasien 2/1; München: Beck).

Weippert, Manfred (2010), Historisches Textbuch zum Alten Testament (Grundrisse zum Alten Testament 10; Göttingen: Vandenhoeck \& Ruprecht).

Weiser, Arthur (1969), Das Buch Jeremia (ATD; Göttingen: Vandenhoeck \& Ruprecht; (sixth printing).

-(1985), Die Propheten Hosea, Joel, Amos, Obadja, Jona, Micha (ATD 24/8; Göttingen: Vandenhoeck \& Ruprecht).

Weitzman, Steve (2002), 'The Samson Story as a Border Fiction', BibInt 10: 159-74.

Welten, Peter (1973), Geschichte und Geschichtsdarstellung in den Chronikbüchern (WMANT 42; Neukirchen-Vluyn: Neukirchener Verlag).

Wesselius, Jan-Wim (2002), The Origin of the History of Israel: Herodotus' Histories as Blueprint for the First Books of the Bible (JSOTSup 345; London: Sheffield Academic Press).

West, Martin L. (1966), Hesiod Theogony (Oxford: Clarendon Press).

-(1997), The East Face of Helicon: West-Asiatic Elements in Greek Poetry and Myth (Oxford: Oxford University Press).

Westermann, Claus (1981), Genesis. 2. Teilband: Genesis12-36 (BKAT I/2; NeukirchenVluyn: Neukirchener Verlag).

Wetter, Anne-Mareike (2014a), 'Ruth - A Born-Again Israelite? One Woman's Journey Through Space and Time', in Ehud Ben Zvi and Diana Edelman (eds), Imagining the Other and Constructing Israelite Identity in the Early Second Temple Period (LHBOTS; London and New York: T \& T Clark Bloomsbury), 144-62.

-(2014b), Judging By Her: Reconfiguring Israel in Ruth, Esther, and Judith (Quaestiones Infinitae 80; Utrecht: Utrecht University).

Whybray, R. Norman (1989), Ecclesiastes (NCB; Grand Rapids: Eerdmans; London: Marschall, Morgan \& Scott).

Wildberger, Hans (1978), Jesaja. Bd. II: Jesaja 13-27 (BKAT 10/2; Neukirchen: Neukirchener Verlag).

-(1980), Jesaja 1-12 (BKAT 10/1, 2nd edn; Neukirchen-Vluyn: Neukirchener Verlag) $=$ ET, Isaiah 1-12: A Commentary (Minneapolis: Fortress, 1991).

Wilk, Florian (2010), 'Between Scripture and History: Technique and Hermeneutics of Interpreting Biblical Prophets in the Septuagint of Isaiah and the Letters of Paul', in Arie van der Kooij and Michaël N. van der Meer (eds), The Old Greek of Isaiah: Issues and Perspectives (CBET 55; Leuven: Peeters), 189-209.

Willi-Plein, Ina (2002), 'Michal und die Anfänge des Königtums in Israel', in Ina Willi-Plein (ed.), Sprache als Schlüssel: Gesammelte Aufsätze zum Alten Testament (Neukirchen-Vluyn: Neukirchener Verlag), 79-96.

Williamson, H. G. M. (1985), Ezra, Nehemiah (WBC 16; Waco, TX: Word Books). -(2001), 'Isaiah and the Holy One of Israel', in Ada Rapoport-Albert and Gillian Greenberg (eds), Biblical Hebrew, Biblical Texts: Essays in Memory of Michael P. Weitzman (JSOTSup 333; London: Sheffield Academic Press), 22-38. 
-(2006), A Critical and Exegetical Commentary on Isaiah 1- 27, vol. 1: Commentary on Isaiah 1-5 (ICC; London: T\&T Clark International).

Wilson, Ian D. (2012), 'Judean Pillar Figurines and Ethnic Identity in the Shadow of Assyria', JSOT 36: 259-78.

Wimmer, Stefan Jakob (2002), 'A New Stela of Ramesses II in Jordan in the Context of Egyptian Royal Stelae in the Levant', 3ICAANE, Paris, 18 April 2002. http://www. stefan-jakob-wimmer.de/3ICAANE_wimmer.pdf

Wiseman, Donald J. (1961), Chronicles of Chaldean Kings (626-556 B.C.) in the British Museum (Reprint of 1956 edn; London: The British Museum).

-(2000), 'Babylonia 605-539 B.C.', in John Boardman et al. (eds), The Assyrian and Babylonian Empires and Other States of the Near East, from the Eight to the Sixth Centuries B.C., 2nd edn (CAH 3/2; Cambridge: Cambridge University Press), $229-51$.

Witulski, Thomas (2010), 'Der Titel Nāśî' bei Ezechiel, in den qumranischen Schriften und bei Bar Kokhba - ein Beitrag zur ideologischen Einordnung des Bar KokhbaAufstandes', Studii Biblici Franciscani Liber Anuus 60: 189-234.

Wolff, Hans Walter (1982), Dodekapropheton 4: Micha (BKAT 14/4); Neukirchen-Vluyn: Neukirchener Verlag.

Wolffenbuttel-van Rooijen, H. (1950), Geschiedenis van het Oude Testament en Geschiedenis van het Nieuwe Testament, vol. 1 (Utrecht: De Fontein).

Woolley, Leonard (1949), 'Introduction', in Sidney Smith (ed.), The Statue of Idri-mi (London: The British Institute of Archaeology), 1-9.

-(1955), Alalakh. An Account of the Excavations at Tell Atchana in the Hatay, 1937-1949 (Oxford: Society of Antiquaries).

Woude, Adam van der (1976), Micha (POT; Nijkerk: Callenbach).

Wright, Benjamin G. (1989), No Small Difference: Sirach's Relationship to its Hebrew Parent Text (SCS 26; Atlanta: Scholars Press).

Wright, Jacob L. (2011), 'War Commemoration and the Interpretation of Judges 5:15b17, VT 61: 505-21.

Wright IV, William M. (2009), Rhetoric and Theology: Figural Reading of John 9 (BZNW 165; Berlin: De Gruyter).

Yadin, Yigael (1965) The Ben Sira Scroll from Masada with Introduction, Emendations and Commentary (Jerusalem: Israel Exploration Society and the Shrine of the Book), reprinted in Masada VI: The Yigael Yadin Excavations 1963-1965, Final Reports (Jerusalem: Israel Exploration Society/The Hebrew University of Jerusalem, 1999), $152-225$.

Yadin, Yigael et al. (1958), Hazor I: An Account of the First Season of Excavations, 1955 (Jerusalem: Magnes Press).

Yassine, Kheïr N. (1975), 'Antropoid Coffins from Raghdan Royal Palace Tomb in Amman', ADAJ 20: 57-68, 165-8.

-(1983), 'El Mabrak: An Architectural Analogue of the Amman Airport Type?', ADAJ 27: 491-3.

Young, Robb A. (2012), Hezekiah in History and Tradition (VTSup 155; Leiden: Brill).

Younger Jr., K. Lawson (2003), 'Assyrian Involvement in the Southern Levant', in Vaughn and Killebrew (2003), 235-63.

Zadok, Ran (2012), 'Occupations and Status Categories (Classes) in Borsippa', Pages in Aharon Oppenheimer and Raz Mustigman (eds), Israel and the Diaspora in the Time of the Second Temple and the Mishnah: Aryeh Kasher Memorial Volume (Te'uda. The 
Chaim Rosenberg School of Jewish Studies Research Series 25; Tel Aviv: Tel Aviv University), XXXI-LXIII.

Zakovitch, Yair (1999), Das Buch Rut: Ein jüdischer Kommentar (SBS 177; Stuttgart: Katholisches Bibelwerk).

Zapff, Burkard M. (1997), Redaktionsgeschichtliche Studien zum Michabuch im Kontext des Dodekapropheton (BZAW 256; Berlin: De Gruyter).

Zenger, Erich (1986), Das Buch Ruth (Zürcher Bibelkommentare 8; Zürich: Theologischer Verlag).

Zevit, Z. (2005), 'Dating Ruth: Legal, Linguistic and Historical Observations', ZAW 117: 574-600.

Ziegler, Joseph (1934), Untersuchungen zur Septuaginta des Buches Isaias (ATAbh 12/3; Münster: Aschendorff).

-(1965), Sapientia Iesu Filii Sirach (Septuaginta Vetus Testamentum Graecum Auctoritate Societatis Litterarum Gottingensis editum XII/2; Göttingen: Vandenhoeck \& Ruprecht).

Zimansky, Paul E. (1985), Ecology and Empire: The Structure of the Urartian State (Studies in Ancient Oriental Civilization 41; Chicago, IL: The Oriental Institute).

Zimmer, Tilmann (1999), Zwischen Tod und Lebensglück: Eine Untersuchung zur Anthropologie Kohelets (BZAW 286; Berlin: De Gruyter).

Zimmerli, Walther (1979), Ezechiel (BKAT XIII/2; Neukirchen-Vluyn: Neukirchener Verlag).

Zorn, Jeffrey R. (1993), 'Tell en-Nașbeh: A Re-Evaluation of the Architecture and Stratigraphy of the Early Bronze Age, Iron Age and Later Periods (Volumes I-IV),' PhD Dissertation Berkeley (Ann Arbor: UMI).

-(2003), 'Tell en-Nașbeh and the Problem of the Material Culture of the 6th Century', in Oded Lipschits and Joseph Blenkinsopp (eds), Judah and the Judeans in the Neo-Babylonian Period (Winona Lake: Eisenbrauns), 413-47. 